\title{
Assessment of port efficiency within Latin America
}

\author{
Kahuina Miller ${ }^{*}(\mathbb{B}$ and Tetsuro Hyodo
}

\section{${ }^{*}$ Correspondence:}

kahuinam@gmail.com Department of Logistics and Information Engineering Tokyo University of Marine Science and Technology, 2-1-6, Etchujima Koto-ku, Tokyo 135-8533, Japan

\begin{abstract}
The Panama Canal expansion has influenced the development of ports within the Latin America and the Caribbean (LAC) region, intending to capitalise on economic opportunities through seaborne trade. Examining port performance is essential to ascertain the PCE impact on port efficiency within the LAC region. Stochastic frontier analysis (SFA) was used to determine the technical efficiency of the 19 major ports within the LAC from 2010 to 2018. The result indicates that, among the four (4) port performance indicators (berth length, port area, the number of cranes (STS gantry and mobile), and the number of berths), the number of STS gantry cranes and berth length had the largest and most significant impact. Some ports with high technical efficiency experienced TEU losses despite port infrastructural development and privatization. The findings also revealed that the increased competition among regional and US East and Gulf Coast ports has negatively impacted some LAC ports'TEU volumes due to port proximity. The dynamism of the maritime sector, especially containerization, requires ports to implement value-added services and logistics centers in tandem with port performance indicators to remain sustainable and competitive in the maritime industry.
\end{abstract}

Keywords: Ports, Technical efficiency, Port performance indicator, Latin America

\section{Introduction}

The evolution in supply chain and logistics models has caused container terminals to rethink their logistics processes. The concept of ports and their functions has evolved throughout the decades. In the nineteenth and twentieth centuries, the port sector tended to be instruments of the state, and port access was deemed to control markets. As a result, there was a minimum competition between ports, and ports related costs were insignificant compared to ocean and inland transport costs, resulting in a lack of initiative to improve port efficiency (PE). Currently, ports are competing globally and reaping tremendous gains from ocean transportation and improvement in logistics. This drive has made the port sectors focus on improving PE, lower cargo throughput handling costs, and providing added value service to catering to other components of the global distribution network (Talley 2017; Notteboom et al. 2021). Port activity and seaborne trade are often associated with positive socio-economic effects, such as GDP and employment growth (Nogué-Algueró 2019; Notteboom et al. 2021; Munim and Schramm 2018; Rodrigue 2020; Talley 2006, 2017). In addition, ports are the drivers of urban author(s) and the source, provide a link to the Creative Commons licence, and indicate if changes were made. The images or other third party material in this article are included in the article's Creative Commons licence, unless indicated otherwise in a credit line to the material. If material is not included in the article's Creative Commons licence and your intended use is not permitted by statutory regulation or exceeds the permitted use, you will need to obtain permission directly from the copyright holder. To view a copy of this licence, visit http:// creativecommons.org/licenses/by/4.0/. 
and regional economic growth, which is a function of port productivity (Lonza and Marolda 2016; Munim and Schramm 2018; Talley 2017; Shetty and Dwarakish 2018).

Port performance indicators (PPIs) is simply defined as a measured aspect of a port's operation to maximize profitability and economic objectives (UNCTAD 2016). Hence a cost-effective port must achieve optimum and technical efficient (TE) throughput to meet its goals (Shetty and Dwarakish 2018; Talley 2006). A port performance measurement depends on several PPIs that affect regional competitiveness and optimum throughput. These factors may vary depending on the port location and region; however, the essential PPIs are berthing capacity, storing capacity, loading/unloading equipment, floor size, and the number of gates lanes (Melalla et al. 2016). Nevertheless, the standard measurement of port performance is related to several factors such as vessel dwell time (DT), loading/unloading the cargo, quality storage, and inland transport (Shetty and Dwarakish 2018). Traditionally, a port performance was assessed by actual throughput and optimum service levels, where the optimum throughput is the maximum (TE) throughput that the port can handle under certain conditions (Talley 2006).

Several authors agreed that PPIs is necessary for rational decision and precise performance measurement. These PPIs reflect port activities that determine overall port performance (Talley 2006; Shetty and Dwarakish 2018; UNCTAD 2016; Munim and Schramm 2018). Port activity can be evaluated using container traffic, voyage productivity, container dwell time, berth area, wharf entrance, departure gates, and port-channel (depth of channel) (Talley 2017; Suárez-Alemán et al. 2016; Figueiredo de Oliveira and Cariou 2015). On the other hand, port performance can be affected by both endogenous and exogenous factors. Endogenous factors involve the port affairs originating from the public and private sectors, such as administration and management inefficiencies. Exogenous factors refer to the shipping and logistics industries and trade economies directly impacting port activities (CEPAL 2019).

The geographical location of ports can also influence port performance. The changing geography of seaports is impacted by technical constraints such as the port users, intermodal connectivity, and maritime shipping networks (Notteboom et al. 2021).

Asian Ports (Singapore, Tianjin, Yokohama, Busan, and Nhava Sheva) have the highest global port performance and rankings. While African ports have displayed mixed trends (Lagos, Durban, and TangerMed) (UNCTAD 2020; World Bank 2019), most developing countries have shown significant advances in port performance and TE (Sarriera et al. 2015; UNCTAD 2020). The Latin America and the Caribbean (LAC) regional ports demonstrated an increase in container throughput during 2000 at 17 million TEUs to 53.4 million TEUs in 2018, representing 6.6\% of global throughput (UNCTAD 2019). The top fifteen ports of LAC, shown in Table 1, have also demonstrated sustained positive container throughput growth (UNCTAD 2020; World Bank 2020).

The Panama Canal (PC) has played a vital role in LAC's port infrastructural developments and transport logistics improvements. The Panama Canal expansion (PCE) has further improved PE among regional ports since the advent of Neo-Panamax ships (Sarriera et al. 2015; Suárez-Alemán et al. 2016; Figueiredo de Oliveira and Cariou 2015). Port infrastructural developments involve; deepening the water channel, acquiring neoPanamax ship-to-shore (STS) cranes and post-Panamax cranes, and port expansion to construct berths and terminals. These developments have fuelled competition within the 
Table 1 Number of terminals by location and specialization. Source: CEPAL (2020)

\begin{tabular}{lccccccc}
\hline Coast & Container & Passenger & Liquid & Dry bulk $\begin{array}{l}\text { Dry and } \\
\text { liquid } \\
\text { bulk }\end{array}$ & Multipurpose & Roll-on/off \\
\hline $\begin{array}{l}\text { East Coast of South } \\
\text { America }\end{array}$ & 37 & 16 & 138 & 16 & 16 & 185 & 19 \\
$\begin{array}{l}\text { West Coast of South } \\
\text { America }\end{array}$ & 12 & 14 & 135 & 86 & 4 & 138 & 1 \\
$\begin{array}{l}\text { The Caribbean } \\
\text { Central America }\end{array}$ & 27 & 53 & 81 & 46 & 1 & 137 & 0 \\
Total & 13 & 25 & 57 & 50 & 5 & 53 & 2 \\
\hline
\end{tabular}

regions where US gulf and East coast ports compete for container traffic. This increasing competition depicts that LAC ports will have to display improving levels of TE to be competitive while maintaining optimum service to satisfy economic objectives to maximize profits (Sarriera et al. 2015; Rodrigue and Notteboom 2021; Talley 2006, 2017). However, it is also essential to determine which PPIs are most significant to port productivity within the LAC region and ascertain whether regional ports have experienced improvements in port performance and TE during the Post-PCE era. A port's productivity depends on the type of PPIs that needs to be measured. The individual performance of each port is vividly measured by the output increase in container throughput (Pallis and Rodrique 2021).

This research seeks to investigate the effect of Panama Canal expansion (PCE) on technical efficiency (TE) for LAC ports during the pre-and post-PCE era among 19 regional ports that account for over $85 \%$ of container throughput (TEUs) by using stochastic frontier analysis (SFA). Our objectives focus on determining port performance indicators (PPIs) necessary to improve LAC regional ports' productivity and efficiency. This study aims to contribute to the body of academic research regarding the Panama Canal expansion (PCE) impact on regional port efficiency (PE) by analyzing the technical efficiency (TE) during the pre and post-PCE era. The rest of the paper is organized as follows; introduction in the first section, "Literature review" section comprises the literature review, "Methodology" section outlines the methodology for empirical analysis employed, "Results" section presents the results, "Discussion" section discusses the findings from the results and limitations, and "Conclusion" section concludes with a key takeaway from our analysis and results.

\section{Literature review}

In this section, we summarize the existing studies in three research areas: (i) the impact of port development on economic growth, (ii) the relationship between dwell time (DT) and port productivity, and (iii) port performance indicator and port efficiency.

\section{Port development and economic growth}

Ports are harbor areas where marine terminal facilities transfer cargo and passengers between ships and land transportation (Rodrigue and Notteboom 2021). Talley (2017) referred to ports as the engine for economic development. Thus, port development is a 
keen driver towards economic growth in a rapidly changing competitive market. Munim and Schramm (2018) studied the impact of port infrastructure and logistics performance on economic growth. The structural equation model (SEM) provided empirical evidence of this objective among 91 countries from 2010 to 2014. The findings revealed that it is of utmost importance for developing countries to continuously improve port infrastructure and logistics to achieve higher yields in economic growth. Mudronja et al. (2020) analyze the effects of seaports on regional growth. Endogenous growth theory based on research and development (R\&D) was used for a sample of 107 ports within the European Union (EU) from 2005 to 2015. The findings revealed that seaports significantly contributed to economic growth among ports within the EU region. The results also showed a close relationship between investment in transportation infrastructure and economic growth. On the other hand, not all port development and productivity contribute to local economic growth. Jung (2011) studied the economic contribution of ports to the local economies in Korea. Content analysis was conducted on port-city, and input-output linkage on ports was investigated. Empirical data of the port throughput and economic indicators were used to find the relationship between ports and the financial performance of major cities in Korea. The results revealed that readily available port services do not guarantee economic success for port cities. Therefore local economies were not benefiting from nearby ports. Consequently, not in all cases does infrastructural expansion contribute to productivity. For example, Herrera and Pang (2008) studied the efficiency of the infrastructure of container ports. They used non-parametric methods to estimate the efficiency of frontiers on 86 ports globally. The results revealed that most ports in developing countries could reduce inefficiency by increasing the scale of operation. However, $33 \%$ of these ports can also reduce inefficiency by contracting the scale of operation.

\section{Dwell time and port productivity}

Port dwell time (DT) is the amount of time a cargo or ship spends within a port (Rodrigue and Notteboom 2021). It is also an indication of the efficiency levels of a seaport (Notteboom et al. 2021). DT impacts port productivity and efficiency; thus, reducing DT will improve port productivity. Port productivity is used frequently to measure and compare the performance of a firm's ratio of output over input, while PE analyses the ability of a port to obtain the maximum result under a given amount of input (SuarezAleman et al. 2016; Talley 2017). Several authors studied the relationship between DT and port productivity. Shetty and Dwarakish (2018) reviewed the relationship between performance parameters and the port's productivity. PPI's data was retrieved from the new Mangalore port from 1990 to 2015. Results revealed a strong negative correlation between idling time at berth, turnaround time of a vessel, and idle time at berth to the port's productivity. Aminatou et al. (2018) studied the impact of long cargo DT on port performance. A shipment level analysis was conducted using original and extensive data on container imports in the Port of Douala, Cameroon. They investigated why containers stay an average exceeding two weeks at berth. Their findings revealed that internal factors such as the logistics performance of consignees, port operations, and the efficiency of customs clearance operations and external factors such as customs procedures, shippers, and shipping lines were the main contributors to long DT. Hassan et al. (2017) 
analyze the DT of containers at container terminals in Indonesia. Root Cause Analysis and Problem Tree framework analyzed operational data and interviews. The results from the simulation revealed that container handling equipment had a significant impact on DT. Finding also revealed that most DT was contributed by a prolonged time of containers stay at the terminal yard.

Understanding and resolving the root cause of long DT at port terminals are essential for improving port productivity and efficiency. Furthermore, predicting the container dwell time is vital for enhancing port operations. According to PortStrategy (2020), the German container terminals will predict DT by implementing a new terminal operation system (TOS) based on machine-learning technology. This system will improve container stacking and optimize pick-up handling.

Figure 1 shows the median time spend in port for container ships per LAC country. This DT indicates the overall port productivity of the country. For example, Panama and Colombia have the least time delay for increasing vessel traffic at 0.66 days for 3883 vessels and 0.6 days for 3689 vessels, respectively. On the other hand, Argentina has the highest median time in ports, showing 1.46 days for 1104 vessels. DT can also indicate the efficiency of a port's processes and infrastructure (Shetty and Dwarakish 2018).

\section{Port performance indicators (PPIs) and port efficiency (PE)}

\section{Port performance indicators (PPIs)}

PPIs are used to measure various aspects of a port's operation. The weight of these indicators may vary based on location, throughput volumes, nature of cargoes, port infrastructure, equipment, and facilities (Melalla et al. 2016; Talley 2017). These indicators measure a port's performance by monitoring activities, checking their efficiency, and comparing the present with past performance (Shetty and Dwarakish 2018; Notteboom et al. 2021). Port performances require a set of measures related to vessel dwell time, cargo throughput volumes, berth area, harbor depth, quality storage, and inland transport (Shetty and Dwarakish 2018). However, not all measurements are related to a port's physical infrastructure.

Langen et al. (2007) Studied the feasibility of using performance indicators from the airport and the business industries to the port sector. New indicators such as services

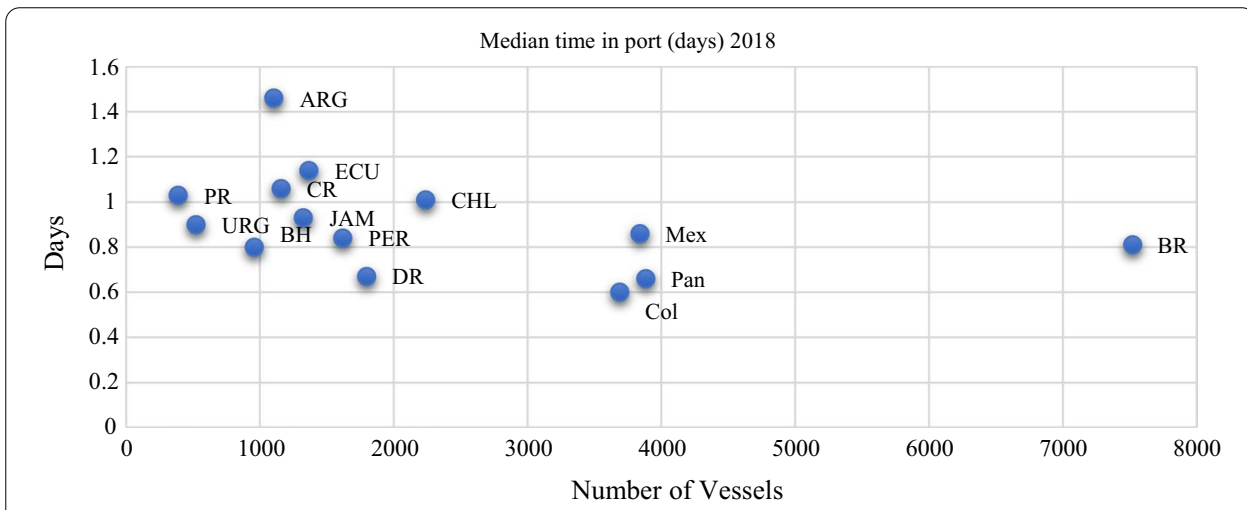

Fig. 1 Median time (days) and number of vessels (No.) for leading container ports (country) within LAC. Source: World Bank (2020) 
variability and average time to deliver cargo could potentially measure port performance. Furthermore, they analyzed performance indicators in other economic and spatial entities such as airports, regional economies, and business parks. The results revealed that these new PPIs would be useful for the port industry.

\section{Port efficiency (PE)}

PE analyses the ability of a port to obtain the maximum output under a given amount of inputs. Therefore, gains in efficiency represent an improvement in performance closer to optima (Suarez-Aleman et al. 2016). PE is a keen component of port performance (Notteboom et al. 2021). Several authors studied the effects of PE on transportation cost, trade, port competition, and socio-economic issues.

Serebrisky et al. (2016) explored the driver of PE in LAC. The Stochastics Frontier model developed a TE evaluation on container ports within LAC. Using data from 1999 to 2009 among 63 ports of container throughput, port terminal area, berth length, and the number of available cranes. The finding revealed an overall improvement in the average TE of ports within the region, from 52 to $64 \%$. Furthermore, the results showed a positive and strong correlation between TE and private port operation.

Pérez et al. (2016) analyzed the development of major container terminals within LAC. The paper's main objective was to investigate factors that influenced container port inefficiency among inter-port and intra-port competition. Stochastic Production Frontier was used for this analysis for all LAC ports from 2000-2010. The results revealed that $\mathrm{PE}$ within the LAC has positively evolved despite the economic crisis, whereby container terminals located among Mercosur countries with three or four container terminals were more efficient than transshipment ports within the region. Interestingly, transshipment ports were least efficient than other types of ports.

Merk and Dang (2012) studied the global PE for container and bulk cargo. Data envelopment analysis (DEA) methodology was used to find the overall efficiency score of 63 of the largest international container ports. The findings revealed that ports with noticeable increases in TE showed significant improvement in PE. Also, promoting port policies to raise throughput levels was essential for improving production scale inefficiencies. However, they also found production scale inefficiency increases whenever a port throughput level is below or above optimum operating terminal capacity. This inefficiency was predominantly found for ports that handled crude oil and iron ore, suggesting that efficiency was affected by exogenous factors relating to traffic flow.

Blonigen and Wilson (2007) studied PE and Trade flow. The Gravity trade model was used to analyze US imports and associated imports cost, yielding estimates across ports, products, and time. The results revealed that PE significantly increases trade volumes.

Clark et al. (2004) examined shipping costs to the United States using 300,000 observations per year on the shipments of products accumulated for various global ports. They found that PE was an essential element of shipping costs. Enhancing PE from the 25th to the 75 th percentile reduced shipping costs by $12 \%$. Overall, their research revealed that a port's (in) efficiency also increased handling and shipping costs.

Figueiredo de Oliveira and Cariou (2015) studied competition on container port (in) efficiencies. They investigated competition impacts on container PE scores at regional, local and global levels. Using truncated regression with Bootstrapping model for 200 
container ports from the period 2007 to 2010. Results revealed that PE decreased with competition intensity varies with distance. For instance, regional range from 400 to $800 \mathrm{~km}$, local range from less than $300 \mathrm{~km}$, and global level more than $800 \mathrm{~km}$ were insignificant at all three levels. Estimates also show a tendency for ports that invested from 2007 to 2010 to experience a general decrease in efficiency scores, which the time lag between the investment could explain.

Tongzon and Heng (2005) examined port privatization, efficiency, and competitiveness. They also investigate the determinants of port competitiveness using principal component analysis and Linear regression model among international container terminals. The results of the study revealed that private sector participation in the port industry could improve port efficiency, therefore, increasing port competitiveness.

The efficiency of ports can be affected by endogeneity and exogenous factors. Several authors extensively studied the link between PE in relation to corruption and socio-economic issues. Suarez-Aleman et al. (2016) examine the drivers of productivity and the efficiency changes for ports among developing regions. Using data from the period 2000 to 2010. The results revealed that PE for developing regions improved, increasing from 51 to $61 \%$ in 2010 . The analysis indicated public sector corruption that PE in developing countries could be improved if there were reduced ship liner connectivity improvements and increased multimodal connectivity among ports.

Several authors' studies revealed a positive link between port productivity and economic growth (Mudronja et al. 2020; Munim and Schramm 2018; Talley 2006). Furthermore, most research revealed that PE positively impacts trade volumes, freight transport, shipping cost, and DT (Shetty and Dwarakish 2018; Aminatou et al. 2018; Hassan et al. 2017; PortStrategy 2020). The authors also connect exogenous and endogeneity factors such as corruption and social-economic factors negative relationship to PE (Serebrisky et al. 2016; Pérez et al. 2016; Merk and Dang 2012). However, little research analyses the PCE influence on PE among the LAC region. The SFA model will address this research gap to determine the most significant PPIs towards PE and regional competitiveness.

\section{Methodology LAC profile}

The LAC region is a diverse economy that is mainly export-driven. This region comprises thirty-three (33) countries that are divided into three (3) sub-regions; South America, Central America, and the Caribbean. Figure 2 shows the main sub-regions of Central America, the Caribbean, the east coast of South America (ECSA), Mexico (both coasts), the north coast of South America (NCSA), and the west coast of South America (WCSA).

\section{LAC port system}

The rapid increase in global container trade in the past two decades has significantly influenced the LAC region's port geography (Wilmsmeier and Monios 2016). The LAC system can be classified by territory and coastline into Central America (split by East and West coast), South America (split by East, West, and North Coast), and the Caribbean. The geographic location of the LAC region, as shown in Table 1 and Fig. 2, consists of 575 terminals on the eastern coast of South America, representing $38 \%$ of the regional total. In comparison, 390 terminals were located on the western 


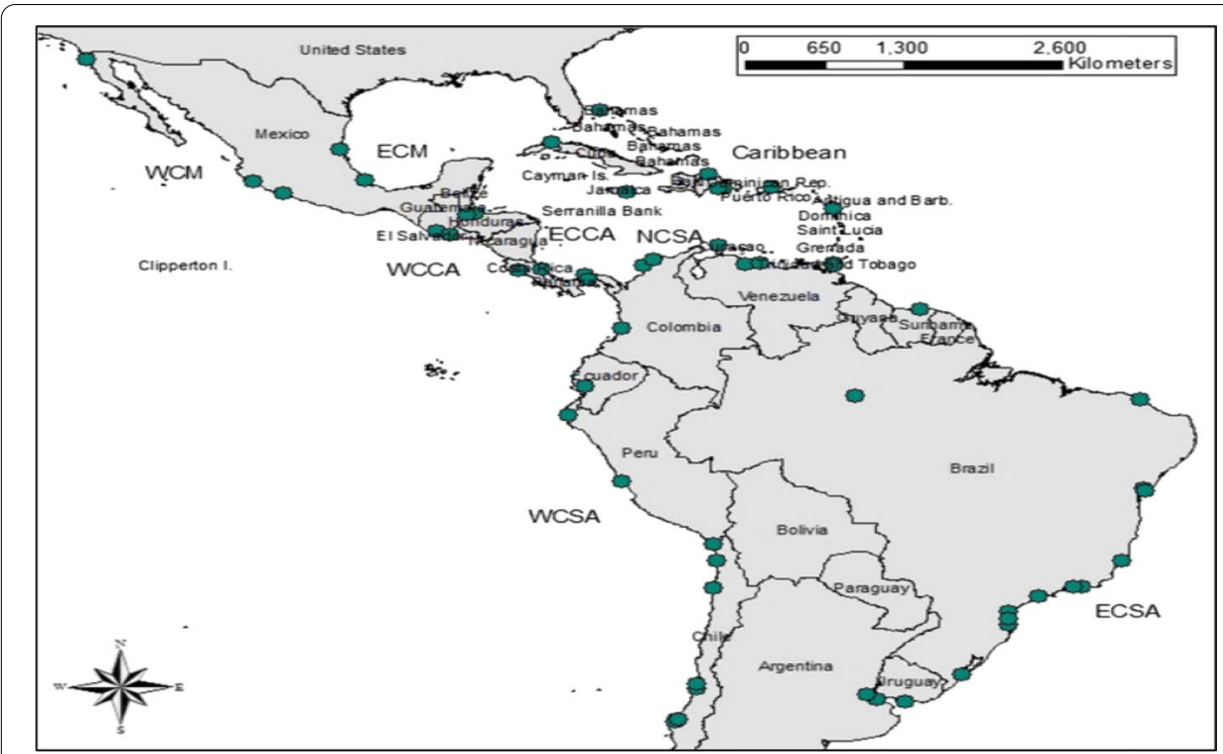

Fig. 2 Map shows Latin America's and the Caribbean port system (TEU). Source: Wilmsmeier and Monios (2016)

coast of South America, representing 25.7\% of the regional total (Wilmsmeier and Monios 2016). In addition, the Caribbean has 345 terminals, representing 22.5\% of the regional total (22.8\%), and Central America has 205 terminals, representing 13.8\% (CEPAL 2020). Table 1 shows the number of terminals in the region: South America (East coast and West coast) has 49 container terminals, the Caribbean has 27 container terminal ports, and Central America has 13 container terminals.

The quality of port infrastructure (QPI) measured business executives' perception of their country's port facilities where WEF $(1=$ extremely underdeveloped to $7=$ well developed and efficiency by international standards) as shown in Table 2. Panama tops the region's ranking at 5.7, proving that SFA results were justifiable overall port performance. Brazil had the lowest overall rank at 3.2; however, Brazil comprises 175 ports; therefore, only top-performing ports were considered because each port will have different TE performance and QPI.

Table 3 shows the port infrastructure and the average annual throughput of each port. The data period spans eight years, from 2010 to 2018. Displaying keen port infrastructural indicators such as berth length, port area, number of mobile and quay cranes, ship-to-ship (STS) gantry cranes, number of berths, draft, transshipment, and the annual container throughput in TEUs.

Table 4 shows that all ports recorded significant growth except for regional ports in Central America and the Caribbean that Balboa Panama (- 9\%), Kingston; Jamaica $(-3 \%)$, San Juan; Puerto Rico $(-8 \%)$, and Freeport; Bahamas $(-7 \%)$ for the 2010 to 2018 period.

\section{Influential factors that affect port efficiency (PE) within the LAC}

The maritime industry is dynamic and responsive to global economic changes; therefore, several factors have influenced port development and efficiency during 
Table 2 Quality of Port Infrastructure among the 19 top Port countries in Latin America and the Caribbean. Source: World Bank (2020)

\begin{tabular}{lllllllllll}
\hline Country & $\mathbf{2 0 1 0}$ & $\mathbf{2 0 1 1}$ & $\mathbf{2 0 1 2}$ & $\mathbf{2 0 1 3}$ & $\mathbf{2 0 1 4}$ & $\mathbf{2 0 1 5}$ & $\mathbf{2 0 1 6}$ & $\mathbf{2 0 1 7}$ & $\mathbf{2 0 1 8}$ & $\mathbf{2 0 1 9}$ \\
\hline Argentina & 3.8 & 3.7 & 3.6 & 3.7 & 3.7 & 3.8 & 3.8 & 3.7 & 3.7 & 3.9 \\
The Bahamas & $\mathrm{Na}$ & $\mathrm{Na}$ & $\mathrm{Na}$ & $\mathrm{Na}$ & $\mathrm{Na}$ & $\mathrm{Na}$ & $\mathrm{Na}$ & $\mathrm{Na}$ & $\mathrm{Na}$ & $\mathrm{Na}$ \\
Brazil & 2.9 & 2.7 & 2.6 & 2.7 & 2.7 & 2.7 & 2.7 & 3.1 & 3.1 & 3.2 \\
Colombia & 3.5 & 3.4 & 3.2 & 3.5 & 3.7 & 3.6 & 3.6 & 3.8 & 4 & 4.1 \\
Costa Rica & 2.7 & 2.3 & 2.4 & 2.9 & 3 & 3.1 & 3.1 & 3.4 & 3.5 & 3.9 \\
Dominican Republic & 4.4 & 4.4 & 4.7 & 4.6 & 4.6 & 4.5 & 4.5 & 4.8 & 4.6 & 4.9 \\
Ecuador & 3.7 & 3.8 & 3.9 & 4.2 & 4.2 & 4.8 & 4.8 & 4.6 & 4.4 & 4.5 \\
Jamaica & 5.3 & 5.3 & 5.1 & 5.1 & 4.9 & 4.7 & 4.7 & 4.9 & 4.5 & 4.5 \\
Mexico & 3.7 & 4 & 4.3 & 4.4 & 4.3 & 4.3 & 4.3 & 4.3 & 4.3 & 4.3 \\
Panama & 6 & 6.4 & 6.4 & 6.4 & 6.3 & 6.3 & 6.3 & 6.2 & 5.7 & 5.7 \\
Peru & 3.3 & 3.5 & 3.5 & 3.7 & 3.7 & 3.6 & 3.6 & 3.7 & 3.6 & 3.8 \\
Puerto Rico & 5.4 & 5.3 & 5.2 & 5.3 & 5.4 & 5.4 & 5.4 & 5.4 & 5.4 & 5.4 \\
Paraguay & 3.4 & 3.4 & 3.6 & 3.4 & 3.2 & 3.1 & 3.1 & 3.3 & 3.4 & 3.5 \\
Uruguay & 5.2 & 5.1 & 4.9 & 4.7 & 4.7 & 4.7 & 4.7 & 4.9 & 4.8 & 4.8 \\
Chile & 5.4 & 5.2 & 5.2 & 5.2 & 5.2 & 5 & 4.9 & 4.9 & 4.6 & 4.9 \\
\hline
\end{tabular}

the pre and post PCE era. Factors include trade policy, port liner shipping connectivity, and the world seaborne trade growth.

\section{Trade policy influence on trade}

Trade plays an integral role in ending global poverty because it has a positive and statistically significant impact on economic growth (World Bank 2020). Open trade and investment with the rest of the world are essential to sustainable economic growth, mainly determined by the type of trade policies in place (IMF 2001). Trade Policy allows bilateral trade among countries to improve exports and imports. Although several studies support that port efficiency (PE) positively impacts trade (Tongzon 1995; Shetty and Dwarakish 2018). However, a port's ability to handle export and import volumes efficiently indicates a level of port performance. Naanwaab and Diarrassouba (2013) studied the influences of economic freedom on bilateral trade in intra-African. Their findings revealed that trade agreements (trade policy) positively impact bilateral trade among African countries. Further results indicated that port inefficiencies in Africa had hindered trade growth. On the contrary, not all trade policies are beneficial. According to Tran (2019), Trade freedom (TRFR) inhibits trade and economic development among some ASEAN countries (Fig. 3).

Trade Freedom (TRFR) Index for Latin America and the Caribbean (LAC), as shown in Fig. 4. declined from 74.8 in 2007 to 74.6 in 2014, then rebounded to 74.7 in 2018. Overall, showing improvements in Trade Freedom (TRFR) within the region.

\section{Port liner shipping connectivity index (PLSCI) in LAC}

The Port liner shipping connectivity index (PLSCI) assesses how well a country links to the global shipping networks (UNCTAD 2021a, b). The LSCI is measured by five 
Table 3 Key port infrastructural indicators for the 19 LAC ports. Source: Own elaboration

\begin{tabular}{|c|c|c|c|c|c|c|c|c|}
\hline $\begin{array}{l}\text { Country/ } \\
\text { ports }\end{array}$ & $\begin{array}{l}\text { Ave annual } \\
\text { throughput } \\
\text { (TEU) } \\
2010-2018\end{array}$ & $\begin{array}{l}\text { Ave. } \\
\text { berth } \\
\text { length } \\
(\mathrm{m})\end{array}$ & $\begin{array}{l}\text { Ave. area } \\
\left(\mathrm{m}^{2}\right)\end{array}$ & $\begin{array}{l}\text { Ave. mobile } \\
\text { crane with } \\
\text { capacity }>1 \\
4 \mathrm{t}(\text { No.) }\end{array}$ & $\begin{array}{l}\text { Ave. STS } \\
\text { gantry } \\
\text { cranes } \\
\text { (No.) }\end{array}$ & $\begin{array}{l}\text { Ave. } \\
\text { depth } \\
\text { (m) }\end{array}$ & $\begin{array}{l}\text { Ave. } \\
\text { container } \\
\text { (No.) }\end{array}$ & $\begin{array}{l}\text { Ave. } \\
\text { berth } \\
\text { (No.) }\end{array}$ \\
\hline $\begin{array}{l}\text { Colon, } \\
\text { Panama }\end{array}$ & $3,483,631$ & 1258 & 384,000 & 33 & 8 & 16.5 & 1258 & 4 \\
\hline $\begin{array}{l}\text { Santos, } \\
\text { Brazil }\end{array}$ & $3,264,961$ & 1980 & 597,000 & 46 & 13 & 16 & 1980 & 65 \\
\hline $\begin{array}{l}\text { Manzanillo, } \\
\text { Mexico }\end{array}$ & $2,311,089$ & 380 & 437,000 & 8 & 9 & 16.5 & 1240 & 13 \\
\hline $\begin{array}{l}\text { Cartagena, } \\
\text { Colombia }\end{array}$ & $2,150,673$ & 270 & 225,000 & 2 & 28 & 21 & 225,000 & 8 \\
\hline $\begin{array}{l}\text { Balboa, } \\
\text { Panama }\end{array}$ & $3,082,469$ & 442 & 300,000 & 8 & 17 & 16.5 & 5 & 7 \\
\hline $\begin{array}{l}\text { El Callo, } \\
\text { Peru }\end{array}$ & 1,908,291 & 183 & 441,080 & 6 & 3 & 16 & 24,300 & 4 \\
\hline $\begin{array}{l}\text { Guayaquil, } \\
\text { Ecuador }\end{array}$ & $1,619,845$ & 1320 & 228,273 & 3 & 6 & 10.5 & 228,273 & 4 \\
\hline $\begin{array}{l}\text { Kingston, } \\
\text { Jamaica }\end{array}$ & $1,717,676$ & 138 & $1,037,671$ & 3 & 19 & 15.5 & 2400 & 11 \\
\hline $\begin{array}{l}\text { Buenos, } \\
\text { Aires, } \\
\text { Argentina }\end{array}$ & $1,608,412$ & 500 & 220,000 & 10 & 13 & 10.7 & 220,000 & 5 \\
\hline $\begin{array}{l}\text { San Anto- } \\
\text { nio, Chile }\end{array}$ & $1,174,939$ & 537 & 495,000 & 6 & 13 & 15 & 495,000 & 9 \\
\hline $\begin{array}{l}\text { San Juan, } \\
\text { Puerto Rico }\end{array}$ & $1,325,861$ & 610 & 287,273 & 0 & 9 & 17 & 287,273 & 46 \\
\hline $\begin{array}{l}\text { Bue- } \\
\text { naventura, } \\
\text { Colombia }\end{array}$ & 901,142 & 440 & 68,500 & 3 & 8 & 15 & 68,500 & 14 \\
\hline $\begin{array}{l}\text { Caucedo, } \\
\text { Dominican } \\
\text { Repulic }\end{array}$ & $1,089,203$ & 922 & 800,000 & 2 & 6 & 15.2 & 800,000 & 15 \\
\hline $\begin{array}{l}\text { Limon } \\
\text { Moin, Costa } \\
\text { Rica }\end{array}$ & $1,075,357$ & 210 & 677,276 & 0 & 6 & 10.2 & 4930 & 6 \\
\hline $\begin{array}{l}\text { Veracruz, } \\
\text { Mexico }\end{array}$ & 900,680 & 507 & 402,909 & 1 & 5 & 14 & 402,909 & 11 \\
\hline $\begin{array}{l}\text { Freeport, } \\
\text { Bahamas }\end{array}$ & $1,204,841$ & 1294 & 320,125 & 0 & 13 & 16 & 57,000 & 3 \\
\hline Itajai, Brazil & $1,010,553$ & 1035 & 180,000 & 3 & 2 & 14 & 180,000 & 4 \\
\hline $\begin{array}{l}\text { Valparado, } \\
\text { Chile }\end{array}$ & 942,106 & 740 & 280,710 & 5 & 3 & 14 & 280,710 & 3 \\
\hline $\begin{array}{l}\text { Altamica, } \\
\text { Mexico }\end{array}$ & 635,007 & 973 & 396,570 & 1 & 4 & 12 & 600 & 12 \\
\hline
\end{tabular}

(5) components of the maritime transport sector: number of ships, container-carrying capacity, maximum vessel size, number of services, and companies that deploy container ships in a country's ports (World Economic Forum 2018). Port infrastructure and PLSCI strongly affect freight rates in the LAC region (Wilmsmeier and Monios 2016). The port liner connectivity is an essential factor influencing trade activity in the maritime industry for regional ports within LAC and US East and Gulf coast. Therefore, PLCSI also indicates the level of efficiency of a port. 
Table 4 LA America and the Caribbean top 19 ports (TEU). Source: Own elaboration

\begin{tabular}{|c|c|c|c|c|}
\hline Port activity & Region & $\begin{array}{l}\text { Throughput } \\
\text { (TEUs) } 2018\end{array}$ & $\begin{array}{l}\text { Compound annual } \\
\text { growth rate, 2010- } \\
2018(\%)\end{array}$ & $\begin{array}{l}\text { Growth rate } \\
2010-2018(\%)\end{array}$ \\
\hline Colon, Panama & Central America & $4,324,478$ & 5.8 & 57 \\
\hline Santos, Brazil & South America & $3,836,487$ & 4.4 & 41 \\
\hline Manzanillo, Mexico & Central America & $3,078,505$ & 9.3 & 104 \\
\hline Cartagena, Colombia & South America & $2,064,281$ & 3.4 & 31 \\
\hline Balboa, Panama & Central America & $2,520,587$ & -1.1 & -9 \\
\hline El Callo, Peru & South America & $2,340,657$ & 7.2 & 74 \\
\hline Guayaquil, Ecuador & South America & $2,064,281$ & 9.0 & 99 \\
\hline Kingston, Jamaica & Caribbean & $1,833,053$ & -0.4 & -3 \\
\hline Buenos Aires, Argentina & South America & $1,797,955$ & 0.5 & 4 \\
\hline San Antonio, Chile & South America & $1,660,832$ & 8.4 & 91 \\
\hline San Juan, Puerto Rico & Caribbean & $1,405,348$ & -1.0 & -8 \\
\hline Buenaventura, Colombia & Caribbean & $1,369,139$ & 9.5 & 107 \\
\hline $\begin{array}{l}\text { Caucedo, Dominican Republic } \\
\text { (DR) }\end{array}$ & Caribbean & $1,331,907$ & 3.6 & 33 \\
\hline Limon Moin, Costa Rica & Central America & $1,187,760$ & 4.1 & 38 \\
\hline Veracruz, Mexico & Central America & $1,176,253$ & 7.4 & 78 \\
\hline Freeport, Bahamas & Caribbean & $1,050,140$ & -0.9 & -7 \\
\hline Itajai, Brazil & South America & $1,045,813$ & 3.2 & 29 \\
\hline Valparado, Chile & South America & 903,296 & 0.3 & 3 \\
\hline Altamica, Mexico & Central America & 820,092 & 6.7 & 68 \\
\hline
\end{tabular}

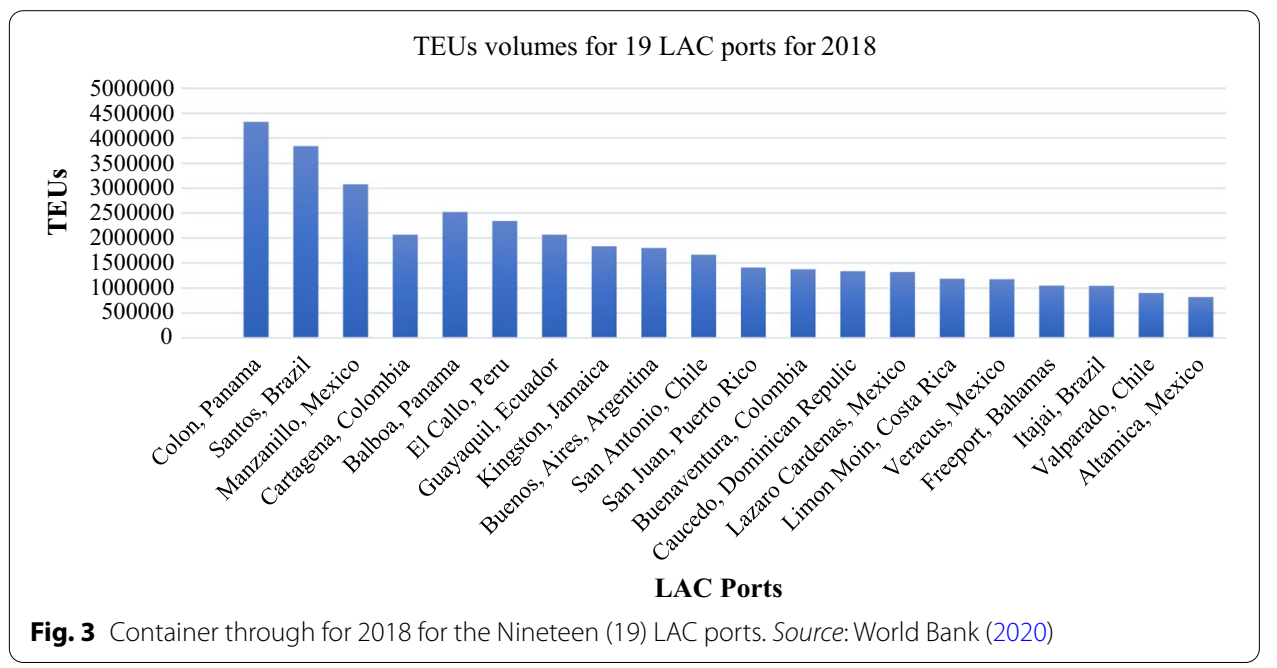

In recent times within the LAC region, the global recession has influenced significant consolidation of shipping lines, whereby shipping lines were forced to reduce cost and optimize ship deployment and services to their customers. Overall, this has led to a higher concentration of container handling among regional ports (Caribbean Development Bank (CDB) 2017). For example, G6 Alliance was established during that period consisting of Hapag-Lloyd, NYK Line, OOCL, Hyundai Merchant Marine, APL, and Mitsui O.S.K. Lines. The merger between Maersk and MSC, forming the $2 \mathrm{M}$ alliance. And several other international and regional unions not listed have influenced port 

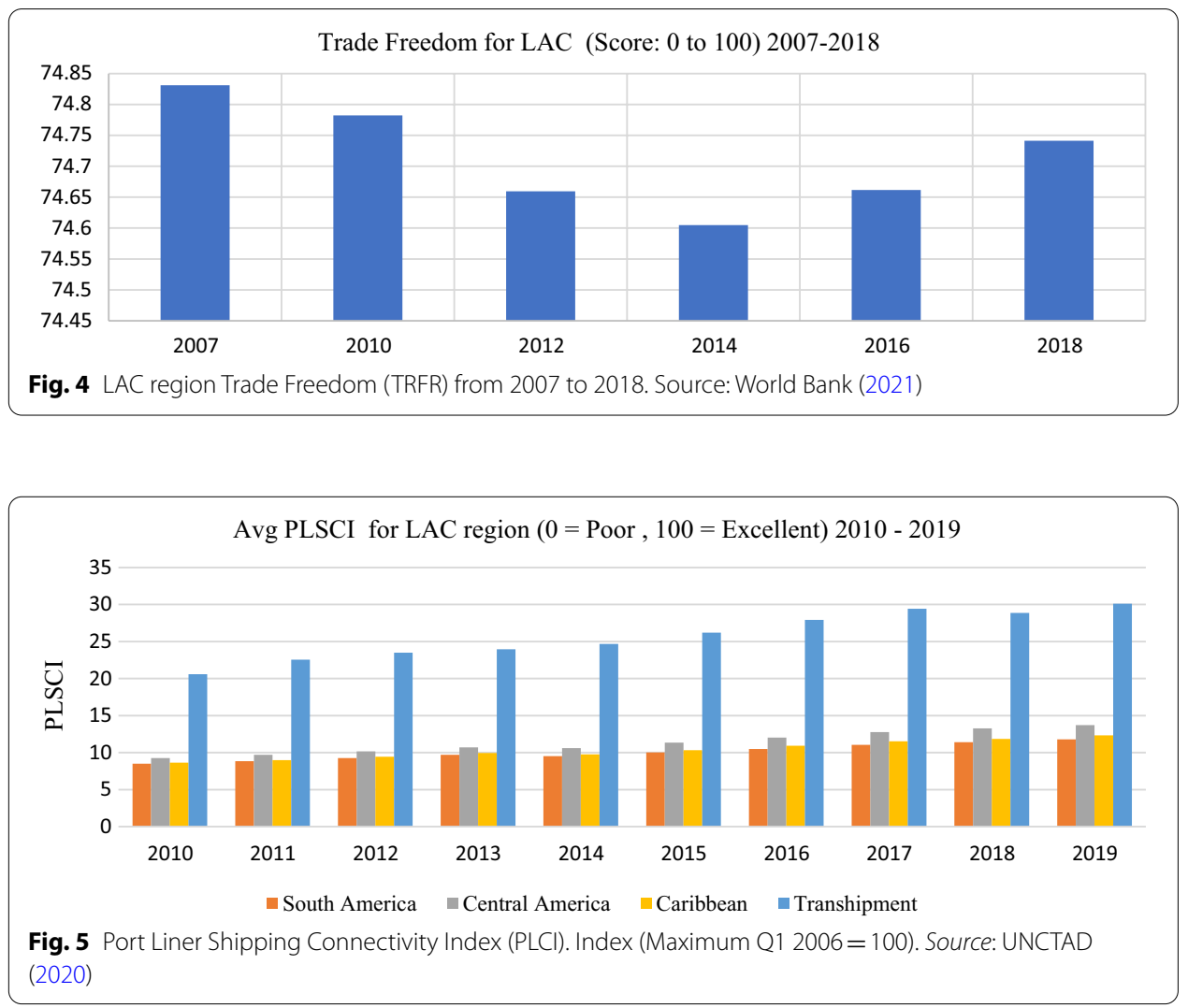

efficiency (PE) within the region (Rodrigue and Notteboom 2021; CDB 2017; UNCTAD 2021a, b).

The average Port Liner Shipping Index (PLSCI) for the three (3) regions showed consistent growth in South America, Central America, and the Caribbean. As shown in Fig. 5, for South America (SA), the PLSCI score increases from 8.50 (2010) to 12.40 (2019), Central America (CA) score increases from 8.63 (2010) to 13.82 (2019), and the Caribbean score from 8.63 (2010) to 12.41 (2019). Also, for transshipment ports, the PLSCI is significantly higher than the overall regional port. The PLSCI for transshipment ports increases from 20.6 (2010) to 30.1 (2019).

\section{World seaborne trade influence on economic growth and port development}

Port is the gateway of trade therefore, as trade increases so will economic growth. According to UNCTAD (2021a, b), around $80 \%$ of volume trade in goods is carried by sea, by which the percentage is higher for developing countries. Several authors link port development, trade, and maritime transport to economic growth (Munim and Schramm 2018; Talley 2017; Gani 2017). Therefore investments towards port development in tandem with logistics infrastructure will improve PE and positively influence economic growth (Munim and Schramm 2018). Poor port and logistics infrastructures among developing countries increase the costs and time required for trade (Töngür et al. 2020; Gani 2017). For example, small Caribbean states have high transportation costs because of the inadequate port infrastructure that has hindered the efficient movement 
of goods (Munim and Schramm 2018). Trade has a direct impact on GDP growth, therefore, as PE improves through infrastructural development as a result trade volume will be enhanced. Figure 6 shows that the growth of the LAC's GDP with Seabourne trade \% (Tonnage) is highly correlated.

\section{Different approaches to technical efficiency frontiers}

Data envelopment analysis (DEA) and stochastic frontier analysis (SFA)

The assessment of multiport performance for TE of ports was conducted using the Frontier models. TE is usually calculated using two approaches, DEA and SFA, where both rely on the estimation efficiency frontier. The Frontier is most frequently used to determine the best performance of data sample information (Serebrisky et al. 2016) while, the DEA is commonly used for multiport TE assessment. According to Talley (2017), DEA is a mathematical programming technique used to derive and estimate TE rating for a group of ports relative to each other. However, the main drawback to this approach is that it assumes sample measurement errors and random variation (Serebrisky et al. 2016).

SFA refers to a body of statistical techniques used to evaluate a port inefficiency by estimating performance and productivity. (Encyclopedia 2021; Aigner et al. 1977). SFA relies on the parametric estimation of the production function with a stochastic component (Kuosmanen and Kortelainen 2010). The error term of SFA is comprised of two random effects that depict statistical noise and other TE. Table 5 shows the main characteristic of DEA and SFA.

Cullinane et al. (2006) use both DEA and SFA approaches to analyze the performance of the world's largest container ports and compare the findings. The results revealed a high level of TE for private-sector-owned and transshipment ports than gateway ports. Similarly, Notteboom et al. (2000) presented an approach for assessing the container terminal efficiency using the Bayesian stochastic frontier modeling. The model was tested using a sample of thirty-six (36) European container terminals and four (4) Asian container ports. The results revealed that feeder ports were less efficient than terminals located in hub ports. Finally, Yang et al. (2011) used SFA and other inefficiencies such as Delphi technique models to evaluate the efficiency of

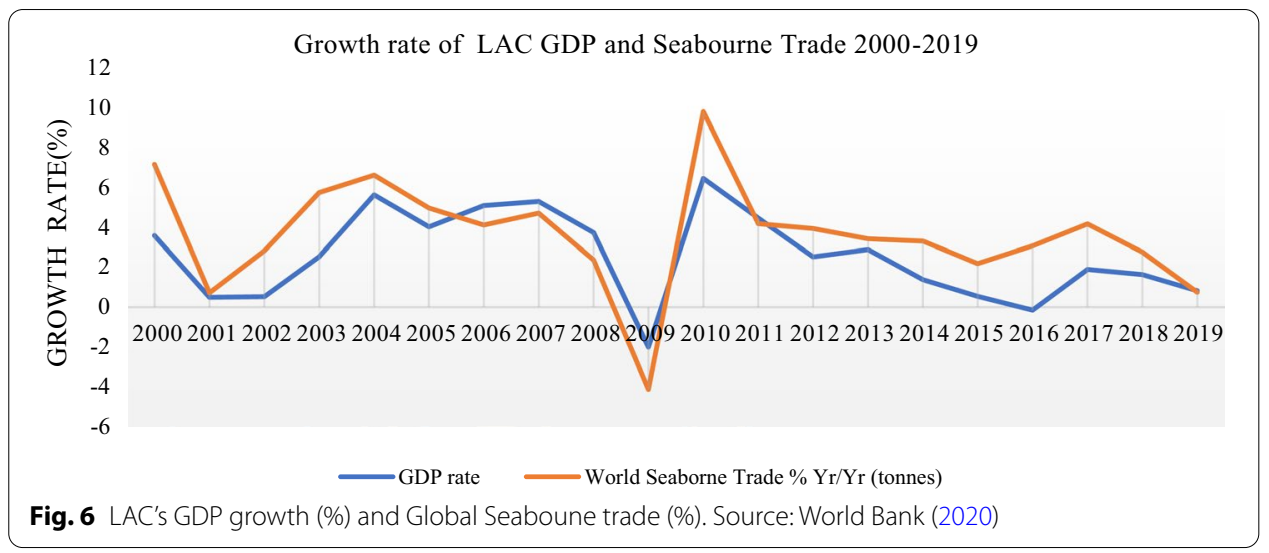


Table 5 Characteristics of DEA and SFA. Source: Serebrisky et al. (2016)

\begin{tabular}{ll}
\hline DEA & SFA \\
\hline Non-parametric approach & Parametric approach \\
Deterministic approach & Stochastic approach \\
Does not consider random noise & Consider random noise \\
Does not allow statistical hypotheses to be contrast & Allow statical hypotheses to be contrasted \\
Does not include an error term & Imposes assumptions on the distribution of the inefficiency \\
& term \\
Does not require specifying a functional form & Requires specifying a functional form \\
Sensitive to the number of variables measurement & $\begin{array}{l}\text { Can confuse inefficiency with a poor specification of the } \\
\text { errors and outliers }\end{array}$ \\
Estimation method: mathematical programming & Estimation method: econometric \\
\hline
\end{tabular}

seaport operations. The study results highlight areas of seaport operations that need to be resolved and show which characteristic needs rectification.

The SFA model was applied and supported by several authors to calculate the TE of port performance; both the DEA and SFA were used in various articles to analyze the TE. The two approaches have different strengths and weaknesses. DEA is sensitive to measurement errors or noise within the in data because of its deterministic approach. However, the SFA considers stochastic noise in data and allows statistical testing of hypotheses concerning production structure and degree of inefficiency as shown in Table 5. The SFA model will assess the port performance of Nineteen (19) top-performing ports within LAC regions. The results will be necessary to determine the PCE impact on top regional ports and the TE since the expansion.

\section{Model}

The characteristic of ports within the LAC region varies in infrastructure and added value services. The accommodation of Neo-Panamax port is the main agender for port development through the upgrade and acquisition of neo-Panamax compatible equipment such as cranes, hinterland expansion, and deepening of water channels. The PCE has fueled the port project among the region's major ports that seek to capitalize on container throughput and added value service, logistics hubs, and ship repairs. Table 4 shows the characteristics and profiles of the 19 top regional ports that account for $85 \%$ of regional container throughput.

SFA is a method used to calculate a port or firm's TE. It is known as comprised error, model for production function $y_{i}=g\left(x_{i}, \beta\right)+\varepsilon_{i}(i=1,2,3, \ldots, N)$. Where $y_{i}$ is the output for statement $i, x_{i}$ is a vector of input for statement $i, \beta$ is the vector of parameters, $\varepsilon_{i}$ is error term for statement $i$, postulates that the error term $\varepsilon_{i}$ is made up of two independent components, $y_{i}=g\left(x_{i}, \beta\right)+\varepsilon_{i}(i=1,2,3, \ldots, N), \varepsilon_{i}=v_{i}-u_{i}$ where $v_{i}$ is a two-side error term representing statistical noise in any relationship; $u_{i}>0$ is one-side error term representing technical inefficiency. The exponential form of the proposed model giving production function in Eq. (1) as,

$$
y_{i t}=\exp \left(x_{i t} \beta+v_{i t}-u_{i t}\right)
$$


where $\mathrm{y}_{\mathrm{it}}$ is the production at the $\mathrm{t}^{\text {th }}$ observation $(t=1,2, \ldots, T)$ for the $i^{\text {th }}$ firm $(i=1,2, \ldots$, $N) ; x_{i t}$ is the logarithm of input variable $\mathrm{v}_{\mathrm{it}}$ is random error assumed to be variance, $N(0$, $\left.\sigma_{v}^{2}\right)$, and independently distributed of a non-negative random variable, $\mathrm{u}_{\mathrm{it}}$. The truncated normal distribution using Wald or generalized likelihood- ratio test is specified in this research to justify the selection of distribution form for technical inefficiency effects.

Regression of effects of inefficiency on the variables that explain inefficiency is given by Eq. (2) as,

$$
u_{i t}=z_{i t} \delta+W_{i t}
$$

$\mathrm{Z}_{\text {it }}$ is a vector of explanatory variable; $\delta$ is a vector of unknown scalar parameters; $\mathrm{W}_{\text {it }}$ is the truncation of normal distribution, $N\left(0, \sigma_{v}^{2}\right)$ truncation is such that point of truncation is $-z_{i t} \delta$. The likelihood function is expressed in terms of variance parameter $\sigma_{s}^{2}=\sigma_{v}^{2}+\sigma_{v}^{2}$ and $\gamma=\sigma / \sigma_{s}^{2}$, inefficiency can therefore be defined in terms of the ratio between observed output and potential output is given input $x_{i t}$ as,

$$
T E_{i t}=y_{i t} / \exp \left(x_{i t} \beta+v_{i t}\right)=\exp \left(-z_{i t} \delta-w_{i t}\right)
$$

\section{Stochastics frontier analysis (SFA) for LAC}

In assessing the PE of 19 LAC ports using an SFA methodology is the production function specification (Cobb-Douglas form) as shown in Eq. (4) below. Time invariant TE is specified as follows.:

$$
\ln \left(Y_{i t}\right)=\beta_{0}+\beta_{1} \ln \left(A_{i t}\right)+\beta_{2} \ln \left(B_{i t}\right)+\beta_{3} \ln \left(C_{i t}\right)+\beta_{4} \ln \left(Q_{i t}\right)+V_{i t}-u_{i t}
$$

These variables are defined as follows:

$$
\forall I=1 \ldots N \text { and } t=1 \ldots T
$$

where $Y_{i t}$ is the container throughput in TEUs handled by port $i$ in period $t ; A_{i t}$ is the total area (in square meters) of the container terminals in port $i$ in period $t ; B_{i t}$ is the total length (meters) of the berths used for container handling in port $i$ in period $t$; $C_{i t}$ is the number of container cranes (Mobile Crane + STS gantry cranes) owned by port $i$ in period $\mathrm{t}$, and the number of berths $\left(Q_{i t}\right)$ is the number of berths in port $i$ in period $t$.

\section{Data}

The data was gathered from nineteen (19) top container ports in the LAC regions; nine (9) ports in South America, six (6) ports in Central America, and four (4) ports in the Caribbean, as shown in Table 3. The database was primarily populated with information published by CEPAL (2019), World Port Source (2021), and World bank (2020). Economic Commission for Latin America and the Caribbean (ECLAC) database gives the Port activity report of container throughput for 31 countries and 118 port and port zones. The World Port source (WPS) gives the profile on each regional port, and the World Bank gives the data on container throughput and ports infrastructural rankings as shown in Fig. 3 and Table 2. 
Table 6 Technical efficiency results for the 19 LAC ports. Period 2010-2018. Source: Own elaboration

\begin{tabular}{|c|c|c|}
\hline Rank & Port/country & $\begin{array}{l}\text { Technical } \\
\text { efficiency } \\
(\%)\end{array}$ \\
\hline 1 & Colon, Panama & 100 \\
\hline 2 & Santos, Brazil & 72 \\
\hline 3 & Manzanillo, Mexico & 85.4 \\
\hline 4 & Cartagena, Colombia & 87.5 \\
\hline 5 & Balboa, Panama & 100 \\
\hline 6 & El Callo, Peru & 100 \\
\hline 7 & Guayaquil, Ecuador & 100 \\
\hline 8 & Kingston, Jamaica & 60 \\
\hline 9 & Buenos, Aires, Argentina & 54.5 \\
\hline 10 & San Antonio, Chile & 43.3 \\
\hline 11 & San Juan, Puerto Rico & 100 \\
\hline 12 & Buenaventura, Colombia & 50.8 \\
\hline 13 & Caucedo, Dominican Republic & 66.6 \\
\hline 14 & Limon Moin, Costa Rica & 74.2 \\
\hline 15 & Veracruz, Mexico & 70.6 \\
\hline 16 & Freeport, Bahamas & 98.5 \\
\hline 17 & Itajai, Brazil & 84.1 \\
\hline 18 & Valparado, Chile & 58.5 \\
\hline 19 & Altamica, Mexico & 55.1 \\
\hline
\end{tabular}

Table 7 Estimation of stochastic production frontier. Source: Own elaboration

\begin{tabular}{llcl}
\hline Variable & Parameter & Coefficient & Standard error \\
\hline Constant & $\boldsymbol{\beta}_{\mathbf{0}}$ & $13.17^{*}$ & $5.77 \mathrm{E}-06$ \\
$B_{i t}$ (berth length) & $\boldsymbol{\beta}_{\mathbf{1}}$ & $-0.0622^{*}$ & 0.0000188 \\
$A_{i t}$ (area of port) & $\boldsymbol{\beta}_{\mathbf{2}}$ & $0.0621^{*}$ & $3.24 \mathrm{E}-06$ \\
$C_{i t}$ (cranes) & $\boldsymbol{\beta}_{\mathbf{3}}$ & $0.2719^{*}$ & $3.29 \mathrm{E}-06$ \\
$Q_{i t}$ (number of berths) & $\boldsymbol{\beta}_{\mathbf{4}}$ & $0.0148^{*}$ & $2.62 \mathrm{E}-04$ \\
\hline
\end{tabular}

${ }^{*}$ Significant at $1 \%$

\section{Results}

The results for TE were derived from the SF model for the period 2010 to 2018; as shown in Table 6, the TE of ports in LAC ranged from 43.3 to 100\%. Port of Colon (Panama), Balboa (Panama), El Callo (Peru), Guayaquil (Ecuador) and San Juan (Puerto Rico) were $100 \%$. South American ports consisted of Santos (72\%), Cartagena (87.5\%), El Callo (100\%), Guayaquil (100\%), Buenos Aires, (54.5\%), San Antonio (43.3\%) Itajai (84.1\%) and Valparaiso (58.5\%). For Central America, the TE results were Port of Colon (100\%), Balboa (100\%), Manzanillo (85.4\%), Limon Moin (74.2\%), and Altamira (55.1\%). For Caribbean Ports, TE were Kingston (60\%), San Juan (100\%), and Caucedo (66.7\%). 


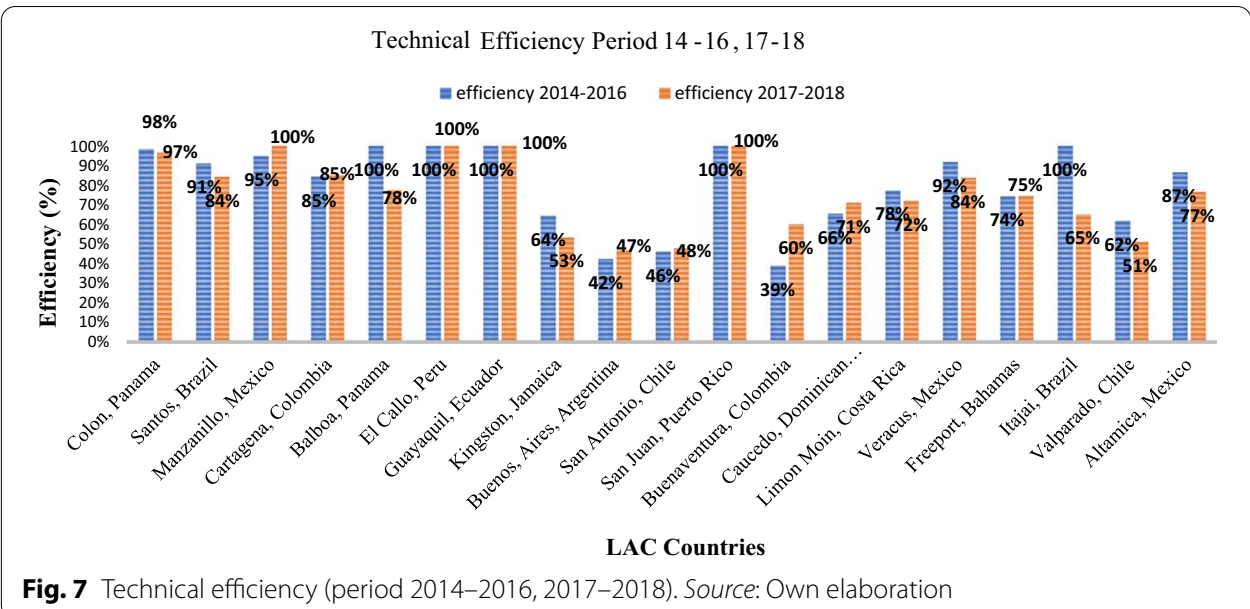

Table 8 Mean technical efficiency per region, pre and post expansion era. Source: Own elaboration

\begin{tabular}{lllc}
\hline Region & $\begin{array}{l}\text { Mean technical efficiency (TE) } \\
(\mathbf{2 0 1 0 - 2 0 1 8 ) ( \% )}\end{array}$ & Pre (\%) & Post (\%) \\
\hline South America & 72 & 72 & 75 \\
Central America & 92 & 92 & 85 \\
Caribbean & 70 & 76 & 75 \\
\hline
\end{tabular}

Table 7 shows Stochastic Frontier analysis results for the 19 LAC ports for output variables: berth length $\left(B_{i t}\right)$, area of port $\left(A_{i t}\right)$, cranes $\left(C_{i t}\right)$, and number of Berths $\left(Q_{i t}\right)$ were all statistically significant at $1 \%$ with the following coefficient, $-0.0622,0.0621$, 0.2719 , and 0.0148 , respectively with log-likelihood was 3.8095 .

The SFA model also revealed that the most TE container terminals are Colon, Balboa, El Callo, Guayaquil, and San Juan; these ports have a TE of 100\%. The port of San Antonio recorded the lowest TE at 43.3\%. The TE results for transhipment ports within the region, Colon (100\%), Santos (72\%), Balboa (100\%), Cartagena (87.5\%), Freeport (98.5\%), Caucedo (66.6\%) and Kingston (60\%).

\section{Pre and post PCE era}

Figure 7 showed that during the pre and post-PCE era, 2014 to 2016 (Before) and 2017 to 2018 (After). The result shows El Callo, Guayaquil, and San Juan maintained 100\% TE. Ports that have improved TE percentages were Manzanillo (95 to 100), San Antonio (46 to 48), Buenos Aires (42 to 47), Buenaventura (39 to 60), Caucedo (66 to 71) and Freeport (74 to 75). Declined TE; Colon (98 to 97), Santos (91 to 41), Balboa (100 to 78), Kingston (64 to 53), Itajai (100 to 65), Valparado (62 to 51) and Altamira (87 to77).

The regional assessment shown in Table 8 reveals that the average TE for South American ports has increased from 72 to $75 \%$ for the pre and post-PCE era. Conversely, Central American ports and Caribbean ports experience a reduction in TE. For example, 


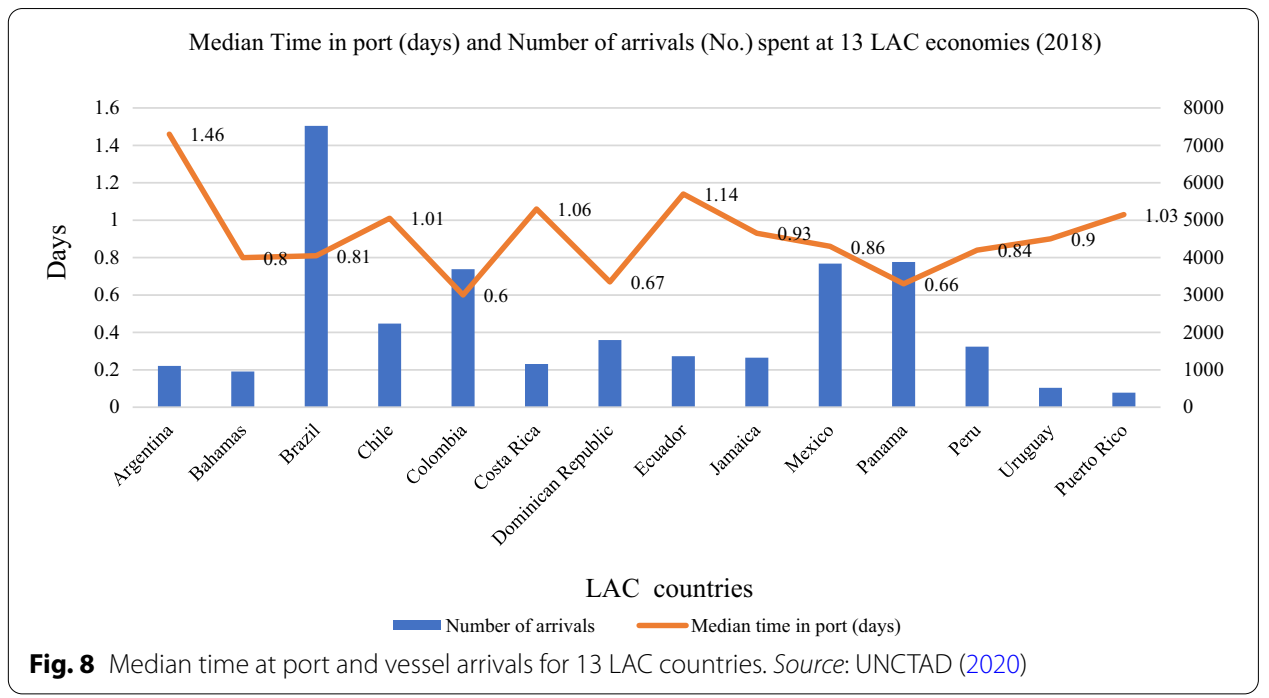

central America had a percentage drop from 92 to 85 while, Caribbean ports experienced a $1 \%$ reduction in TE percentage.

Figure 8 shows the median time spent and the number of vessel arrivals. Colombia, Panama, and Dominican Republic (DR) recorded the lowest time for ships at the port; 0.6, 0.66, and 0.67, respectively. Conversely, Argentina, Ecuador, and Costa Rica have recorded the highest time delay at 1.46, 1.14, 1.06, respectively. For transshipment port countries, Colombia's median time was lowest at 0.6, followed by Panama at 0.66 .

\section{Discussion}

The SFA model results showed that the four (4) output variables, berth length $\left(B_{i t}\right)$, area of port $\left(A_{i t}\right)$, cranes $\left(C_{i t}\right)$, and the number of berths $\left(Q_{i t}\right)$ used in the model, were all statistically significant, as shown in Table 7. All four (4) output variables, had significant increases from 2000 to 2010, as shown in Table 11. However, in Table 9 from 2010 to 2016, only the variable; Cranes $\left(C_{i t}\right)$ had established considerable increases among the 19 major regional ports. During the period 2016 to 2018 as shown in Table 10, all variables had no changes except for the deepening of the harbor for the Port of Kingston; this variable was excluded from the model.

The keen factors in improving port productivity and efficiency are the improvements of port and logistics infrastructures, reducing shipping and handling costs, and lowering DT, which will eventually improve a port's trade volumes and competitiveness (Clark et al. 2004; Töngür et al. 2020; Gani 2017; Merk and Dang 2012; Blonigen and Wilson 2007; Figueiredo de Oliveira and Cariou 2015). Interestingly, the SFA results showed that the coefficient for the crane was 0.2719 , which constituted as having the largest impact than the other variables (Hassan et al. 2017; Suárez-Alemán et al. 2016; Talley 2017; Serebrisky et al. 2016). The PCE had spurred the LAC region towards port investment (Suarez-Aleman et al. 2016; Notteboom et al. 2021). These investments were largely 
focused on the acquisition of STS gantry and neo-Panamax cranes, port hinterland expansion, and for some ports; the deepening of waterways or harbor to accommodate ships with a draft of $15 \mathrm{~m}$ and more (Mudronja et al. 2020; Munim and Schramm 2018; Rodrigue and Notteboom 2021; Serebrisky et al. 2016). Therefore, the utilization of the four (4) output variables $\left(B_{i t}, A_{i t}, C_{i t}\right.$, and $\left.Q_{i t}\right)$ were important components for improving PE and regional competitiveness (Suárez-Alemán et al. 2016; Talley 2017; Rodrigue and Notteboom 2021; Töngür et al. 2020; Gani 2017, Serebrisky et al. 2016).

Table 6, shows that PE results for ports within the LAC vary depending on two factors; (1) a port's ability to handle larger container vessels, and (2) the surge in container throughput (TEUs) due to increases in transshipment activities (Talley 2017; Mudronja et al. 2020; Suárez-Alemán et al. 2016; Clark et al. 2004). On the other hand, some ports especially traditional transshipment ports such as Kingston (Jamaica) and Freeport (the Bahamas) encounter a decline in TEUs due to port proximity, and inefficiencies (Figueiredo de Oliveira and Cariou 2015; Pérez et al. 2016; Clark et al. 2004).

The PCE may play a major role in maritime activities among regional ports however, it is not the only influencing factor for PE improvement (Merk and Dang 2012; SuárezAlemán et al. 2016; Talley 2017; World Bank 2020; UNCTAD, 2021a, b; CDB 2017). Several other factors such as port privatization, trade policy, global economic growth, port liner connectivity, infrastructure, and the culture of corruption, can affect port productivity and efficiency (Tongzon and Heng 2005; Tongzon 1995; Serebrisky et al. 2016; Shetty and Dwarakish 2018; Park et al. 2020; Çelebi 2017; World Bank 2020; UNCTAD 2021a, b). Moreover, port efficiency (PE) in relation to throughput also depends on the port location, frequency of ship calls, port charges, economic activity, and terminal efficiency (Tongzon 1995; Talley 2017; Figueiredo de Oliveira and Cariou 2015; Suarez-Aleman et al. 2016; Jung 2011). For example, the efficiency of a container port depends on the crane efficiency, economies of scale (Vessel size and cargo exchange), work practices, and mixed container (Tongzon, 1995; Shetty and Dwarakish 2018). These PPIs are frequently used to determine PE. Nevertheless, exogenous factors such as governmental trade policies, liner connectivity, economic growth, trade, intermodal connectivity, and logistics infrastructure have impacted regional port performance (Merk and Dang 2012; Serebrisky et al. 2016; Shetty and Dwarakish 2018; Park et al. 2020).

The TE results shown in Table 6; revealed that ports within the region experience different levels of growth in TEUs that depend on their scale of operation (Hassan et al. 2017; Herrera and Pang 2008). PPIs improvements enhance the quality of service to the port users, reduce technical and cost inefficiencies, and increase the port's compatibilities (Talley 2017; Melalla et al. 2016; Shetty and Dwarakish, 2018; Hassan et al. 2017). As shown in Tables 2 and 3, Panama has the highest port infrastructure index and container throughput within the region. The results from the SFA revealed that both the ports of Colon and Balboa showed TE values of 100\% from 2010 to 2018. Argentina has a quality of QPI recorded rank of 3.7, and port of Buenos Aires, TE was 54\%.

A shorter time at a port is a positive indicator of the port's efficiency and trade competitiveness (UNCTAD 2019; Aminatou et al. 2018; Hassan et al. 2017; PortStrategy 2020). 
Therefore, reducing vessel time at the port will accommodate more vessel calls (Tongzon and Heng 2005; Talley 2017; Notteboom et al. 2021). Figure 5; shows the median time vessel spent on region ports. Panamanian and Colombian ports displayed the shortest at 0.67 and 0.6 , respectively. These values correlate to the high level of TE of 100 and $87.5 \%$, respectively. The results clearly, revealed that ports with the shortest time median (dwell time) normally displayed larger TE values.

Port is the gateway to trade and economic growth (Talley 2017; Notteboom et al. 2021). Therefore, improving PE is a necessary component for enhancing a port's productivity and competitiveness for developing countries (Tongzon and Heng 2005; Talley 2017; Serebrisky et al. 2016; Shetty and Dwarakish 2018; Park et al. 2020). The results revealed that for the LAC region four (4) PPIs were significant for PE during the pre and post-PCE era. However, factors such as trade and port policy, liner shipping connectivity, and the utilization of technological innovation can be essential tools to alleviate port congestion and improve dwell time (PortStrategy 2020).

\section{Limitations}

The sample size of this research was taken from the ECLAC (CEPAL), World Port Source, and port website. This sample was among 19 top regional port consisting of transshipment hubs that accounts for over $80 \%$ of container throughput. The limited sample size resulted from the exclusion of smaller ports that provided limited data on berth length, port area, number of cranes, and number of berths. In addition, most small ports cannot accommodate Neopananax and post-Panamax vessels; therefore, throughput volume will be lower than large ports. Thus generalization of the findings is constrained to major ports.

\section{Conclusion}

In order to assess port efficiency (PE) in Latin America and the Caribbean (LAC), Stochastic Frontier Analysis (SFA) was used to determine the technical efficiency (TE) for 19 ports from 2010 to 2018. Container throughput (TEUs) was used as the output variable, whereas berth length $\left(B_{i t}\right)$, port area $\left(A_{i t}\right)$, cranes $\left(C_{i t}\right)$, and number of berths $\left(\mathrm{Q}_{\mathrm{it}}\right)$ were input variables.

The estimation from the SFA indicates productivity from cranes, ship-to-shore (STS) gantry, and berth length had the largest impact and are positively significant. Findings also revealed that LAC countries with low QPI rankings displayed low TE. The pre and post PCE Era highlighted that 'timely' investment towards port development and infrastructural improvements increases productivity and efficiency which is partly influenced by the privatization of ports (Tongzon and Heng 2005; Nogué-Algueró 2019; Notteboom et al. 2021; Munim and Schramm 2018; Rodrigue 2020; Talley 2006; Talley 2017; Serebrisky et al. 2016). For instance, Caucedo (Dominican Republic) and Buenaventura (Colombia) were good examples of these findings; they showed significant 
improvements in TE because of the regional port administration's initiatives towards the improvement and development of ports before the completion of the PCE. Furthermore, most of the top and emerging regional ports executed the long-term strategy of improving port competitiveness through port privatization and policies (Rodrigue and Notteboom 2021; Tongzon and Heng 2005; Merk and Dang 2012; Serebrisky et al. 2016). For instance, CMA-CGM signed a \$509 million, 30-year concession with the Port Authority of Jamaica in 2015. Likewise, APM Terminal signed a \$992 million, 33-year concession with the government of Costa Rica in 2011.

Improvements in PE for the LAC region were not solely influenced by the PCE. Other factors such as trade agreements among Latin American countries were implemented during the pre and post PCE era, for example, the Central America Free Trade Agreement (CAFTA) and Free Trade Area of the Americas (FTAA) (CEPAL 2019). Liner consolidation, port privatization, and the growth of the seaborne trade have certainly had a positive impact on regional port development (Nogué-Algueró 2019; Notteboom et al. 2021; Munim and Schramm 2018; Rodrigue 2020; Talley 2006; Talley 2017; Shetty and Dwarakish 2018).

The results, as shown in Table 8 also, revealed that South American's TE has improved since the PCE, while Central America and the Caribbean have experienced a reduction in TE influenced by the regional port competitions (Bhadury 2016; Park et al. 2020). This reduction could be a result of both port inefficiency and proximity. Take, for instance, Freeport (Bahamas); one of the significant transship hubs have experienced TEUs losses due to the port's proximity to US East coasts ports such as Miami, Everglades, and Charleston (Notteboom et al. 2000; Merk and Dang 2012; Bhadury 2016; Park et al. 2020).

Assessing TE using PPIs can guide port seeking to improve productivity, cost reduction, and competitiveness (Blonigen and Wilson 2007; Serebrisky et al. 2016). PPIs such as berth length $\left(B_{i t}\right)$, terminal Area $\left(A_{i t}\right)$, (STS gantry and mobile) cranes $\left(C_{i t}\right)$, and the number of berths $\left(Q_{i t}\right)$ are crucial areas that investors should focus on to improve productivity. However, other variables such as corruption, type of ownership, added-value services, port proximity, and income classification could further validate the TE results. These variables were not considered within this research. Further studies on these variables may be considered for future research. Overall, the SFA model can be an effective tool for assessing port productivity within the LAC region.

\section{Appendix A: LAC port characteristics}

See Tables 9, 10 and 11. 
Table 9 Port characteristics of LAC average between 2014 and 2016 (Pre-PCE-Era). Source: Own elaboration based on data from World Port Source

\begin{tabular}{|c|c|c|c|c|c|c|c|c|}
\hline $\begin{array}{l}\text { Country/ } \\
\text { ports }\end{array}$ & $\begin{array}{l}\text { Ave. annual } \\
\text { throughput } \\
\text { (TEU) } \\
2014-2016\end{array}$ & $\begin{array}{l}\text { Ave. } \\
\text { berth } \\
\text { length } \\
\text { (m) }\end{array}$ & $\begin{array}{l}\text { Ave. area } \\
\left(\mathrm{m}^{2}\right)\end{array}$ & $\begin{array}{l}\text { Ave. mobile } \\
\text { crane with } \\
\text { capacity }>1 \\
4 \mathrm{t}(\text { No.) }\end{array}$ & $\begin{array}{l}\text { Ave. STS } \\
\text { gantry } \\
\text { cranes } \\
\text { (No.) }\end{array}$ & $\begin{array}{l}\text { Ave. } \\
\text { depth } \\
\text { (m) }\end{array}$ & $\begin{array}{l}\text { Ave. } \\
\text { container } \\
\text { (No.) }\end{array}$ & $\begin{array}{l}\text { Ave. } \\
\text { berth } \\
\text { (No.) }\end{array}$ \\
\hline $\begin{array}{l}\text { Colon, } \\
\text { Panama }\end{array}$ & $3,377,515$ & 1258 & 384,000 & 33 & 8 & 16.5 & 1258 & 4 \\
\hline $\begin{array}{l}\text { Santos, } \\
\text { Brazil }\end{array}$ & $3,359,757$ & 1980 & 597,000 & 46 & 13 & 16 & 1980 & 65 \\
\hline $\begin{array}{l}\text { Manzanillo, } \\
\text { Mexico }\end{array}$ & $2,496,234$ & 380 & 437,000 & 8 & 9 & 16.5 & 1240 & 13 \\
\hline $\begin{array}{l}\text { Cartagena, } \\
\text { Colombia }\end{array}$ & $2,328,538$ & 270 & 225,000 & 2 & 28 & 21 & 225,000 & 8 \\
\hline $\begin{array}{l}\text { Balboa, } \\
\text { Panama }\end{array}$ & $3,250,753$ & 442 & 300,000 & 8 & 17 & 16.5 & 5 & 7 \\
\hline $\begin{array}{l}\text { El Callo, } \\
\text { Peru }\end{array}$ & $1,982,629$ & 183 & 441,080 & 6 & 3 & 16 & 24,300 & 4 \\
\hline $\begin{array}{l}\text { Guayaquil, } \\
\text { Ecuador }\end{array}$ & $1,713,675$ & 1320 & 228,273 & 3 & 6 & 10.5 & 228,273 & 4 \\
\hline $\begin{array}{l}\text { Kingston, } \\
\text { Jamaica }\end{array}$ & $1,619,609$ & 138 & $1,037,671$ & 5 & 13 & 14 & 2400 & 11 \\
\hline $\begin{array}{l}\text { Buenos, } \\
\text { Aires, } \\
\text { Argentina }\end{array}$ & $1,395,294$ & 500 & 220,000 & 8 & 12 & 10.7 & 220,000 & 5 \\
\hline $\begin{array}{l}\text { San Anto- } \\
\text { nio, Chile }\end{array}$ & $1,183,822$ & 537 & 495,000 & 6 & 13 & 15 & 495,000 & 9 \\
\hline $\begin{array}{l}\text { San Juan, } \\
\text { Puerto Rico }\end{array}$ & $1,271,083$ & 610 & 287,273 & 0 & 6 & 17 & 287,273 & 46 \\
\hline $\begin{array}{l}\text { Bue- } \\
\text { naventura, } \\
\text { Colombia }\end{array}$ & 902,841 & 440 & 68,500 & 3 & 8 & 15 & 68,500 & 14 \\
\hline $\begin{array}{l}\text { Caucedo, } \\
\text { Dominican } \\
\text { Repulic }\end{array}$ & 886,859 & 922 & 800,000 & 2 & 6 & 15.2 & 800,000 & 15 \\
\hline $\begin{array}{l}\text { Limon } \\
\text { Moin, Costa } \\
\text { Rica }\end{array}$ & $1,056,951$ & 210 & 677,276 & 1 & 1 & 10.2 & 4930 & 6 \\
\hline $\begin{array}{l}\text { Veracus, } \\
\text { Mexico }\end{array}$ & $1,128,491$ & 507 & 402,909 & 1 & 5 & 14 & 402,909 & 11 \\
\hline $\begin{array}{l}\text { Freeport, } \\
\text { Bahamas }\end{array}$ & 914,825 & 1294 & 320,125 & 0 & 13 & 16 & 57,000 & 3 \\
\hline Itajai, Brazil & $1,333,333$ & 1035 & 180,000 & 3 & 2 & 14 & 180,000 & 4 \\
\hline $\begin{array}{l}\text { Valparado, } \\
\text { Chile }\end{array}$ & $1,058,139$ & 740 & 280,710 & 5 & 3 & 14 & 280,710 & 3 \\
\hline $\begin{array}{l}\text { Altamica, } \\
\text { Mexico }\end{array}$ & 932,258 & 973 & 396,570 & 1 & 4 & 12 & 600 & 12 \\
\hline
\end{tabular}


Table 10 Port characteristics. Average between 2017 and 2018 (Post-PCE-Era). Source: Own elaboration based on data from World Port Source

\begin{tabular}{|c|c|c|c|c|c|c|c|c|}
\hline $\begin{array}{l}\text { Country/ } \\
\text { ports }\end{array}$ & $\begin{array}{l}\text { Ave annual } \\
\text { throughput } \\
\text { (TEU) } \\
2017-2018\end{array}$ & $\begin{array}{l}\text { Ave. } \\
\text { berth } \\
\text { length } \\
\text { (m) }\end{array}$ & $\begin{array}{l}\text { Ave. area } \\
\left(\mathrm{m}^{2}\right)\end{array}$ & $\begin{array}{l}\text { Ave. mobile } \\
\text { crane with } \\
\text { capacity }>1 \\
4 \mathrm{t}(\text { No.) }\end{array}$ & $\begin{array}{l}\text { Ave. STS } \\
\text { gantry } \\
\text { cranes } \\
\text { (No.) }\end{array}$ & $\begin{array}{l}\text { Ave. } \\
\text { depth } \\
\text { (m) }\end{array}$ & $\begin{array}{l}\text { Ave. } \\
\text { container } \\
\text { (No.) }\end{array}$ & $\begin{array}{l}\text { Ave. } \\
\text { berth } \\
\text { (No.) }\end{array}$ \\
\hline $\begin{array}{l}\text { Colon, } \\
\text { Panama }\end{array}$ & $4,107,844$ & 1258 & 384,000 & 33 & 8 & 16.5 & 1258 & 4 \\
\hline $\begin{array}{l}\text { Santos, } \\
\text { Brazil }\end{array}$ & $3,707,340$ & 1980 & 597,000 & 46 & 13 & 16 & 1980 & 65 \\
\hline $\begin{array}{l}\text { Manzanillo, } \\
\text { Mexico }\end{array}$ & $2,954,438$ & 380 & 437,000 & 8 & 9 & 16.5 & 1240 & 13 \\
\hline $\begin{array}{l}\text { Cartagena, } \\
\text { Colombia }\end{array}$ & $2,371,143$ & 270 & 225,000 & 2 & 28 & 21 & 225,000 & 8 \\
\hline $\begin{array}{l}\text { Balboa, } \\
\text { Panama }\end{array}$ & $2,753,602$ & 442 & 300,000 & 8 & 17 & 16.5 & 5 & 7 \\
\hline $\begin{array}{l}\text { El Callo, } \\
\text { Peru }\end{array}$ & $2,295,441$ & 183 & 441,080 & 6 & 3 & 16 & 24,300 & 4 \\
\hline $\begin{array}{l}\text { Guayaquil, } \\
\text { Ecuador }\end{array}$ & $1,967,936$ & 1320 & 228,273 & 3 & 6 & 10.5 & 228,273 & 4 \\
\hline $\begin{array}{l}\text { Kingston, } \\
\text { Jamaica }\end{array}$ & $1,696,527$ & 138 & $1,037,671$ & 3 & 19 & 15.5 & 2400 & 11 \\
\hline $\begin{array}{l}\text { Buenos, } \\
\text { Aires, } \\
\text { Argentina }\end{array}$ & $1,633,457.5$ & 500 & 220,000 & 10 & 13 & 10.7 & 220,000 & 5 \\
\hline $\begin{array}{l}\text { San Anto- } \\
\text { nio, Chile }\end{array}$ & $1,478,861$ & 537 & 495,000 & 6 & 13 & 15 & 495,000 & 9 \\
\hline $\begin{array}{l}\text { San Juan, } \\
\text { Puerto Rico }\end{array}$ & $1,302,253$ & 610 & 287,273 & 0 & 9 & 17 & 287,273 & 46 \\
\hline $\begin{array}{l}\text { Bue- } \\
\text { naventura, } \\
\text { Colombia }\end{array}$ & $1,144,570$ & 440 & 68,500 & 3 & 8 & 15 & 68,500 & 14 \\
\hline $\begin{array}{l}\text { Caucedo, } \\
\text { Dominican } \\
\text { Repulic }\end{array}$ & $1,283,854$ & 922 & 800,000 & 2 & 6 & 15.2 & 800,000 & 15 \\
\hline $\begin{array}{l}\text { Limon } \\
\text { Moin, Costa } \\
\text { Rica }\end{array}$ & $1,231,939$ & 210 & 677,276 & 0 & 6 & 10.2 & 4930 & 6 \\
\hline $\begin{array}{l}\text { Veracus, } \\
\text { Mexico }\end{array}$ & $1,193,694$ & 507 & 402,909 & 1 & 5 & 14 & 402,909 & 11 \\
\hline $\begin{array}{l}\text { Freeport, } \\
\text { Bahamas }\end{array}$ & $1,146,779$ & 1294 & 320,125 & 0 & 16 & 16 & 57,000 & 3 \\
\hline Itajai, Brazil & 950,283 & 1035 & 180,000 & 3 & 2 & 14 & 180,000 & 4 \\
\hline $\begin{array}{l}\text { Valparado, } \\
\text { Chile }\end{array}$ & $1,022,545$ & 740 & 280,710 & 5 & 3 & 14 & 280,710 & 3 \\
\hline $\begin{array}{l}\text { Altamica, } \\
\text { Mexico }\end{array}$ & 988,515 & 973 & 396,570 & 1 & 7 & 12 & 600 & 12 \\
\hline
\end{tabular}


Table 11 Port characteristics. Average between 2000 and 2016. Source: Own elaboration based on data from World Port Source

\begin{tabular}{|c|c|c|c|c|c|c|c|c|}
\hline $\begin{array}{l}\text { Country/ } \\
\text { ports }\end{array}$ & $\begin{array}{l}\text { Ave. annual } \\
\text { throughput } \\
\text { (TEU) } \\
2010-2016\end{array}$ & $\begin{array}{l}\text { Ave. } \\
\text { berth } \\
\text { length } \\
\text { (m) }\end{array}$ & $\begin{array}{l}\text { Ave. area } \\
\left(\mathrm{m}^{2}\right)\end{array}$ & $\begin{array}{l}\text { Ave. mobile } \\
\text { crane with } \\
\text { capacity }>1 \\
4 \text { t(No.) }\end{array}$ & $\begin{array}{l}\text { Ave. STS } \\
\text { gantry } \\
\text { cranes } \\
\text { (No.) }\end{array}$ & $\begin{array}{l}\text { Ave. } \\
\text { depth } \\
\text { (m) }\end{array}$ & $\begin{array}{l}\text { Ave. } \\
\text { container } \\
\text { (No.) }\end{array}$ & $\begin{array}{l}\text { Ave. } \\
\text { berth } \\
\text { (No.) }\end{array}$ \\
\hline $\begin{array}{l}\text { Colon, } \\
\text { Panama }\end{array}$ & $3,258,381$ & 1258 & 384,000 & 33 & 8 & 16.5 & 1258 & 4 \\
\hline $\begin{array}{l}\text { Santos, } \\
\text { Brazil }\end{array}$ & $3,393,593$ & 1980 & 597,000 & 46 & 13 & 16 & 1980 & 65 \\
\hline $\begin{array}{l}\text { Manzanillo, } \\
\text { Mexico }\end{array}$ & $2,578,822$ & 380 & 437,000 & 8 & 9 & 16.5 & 1240 & 13 \\
\hline $\begin{array}{l}\text { Cartagena, } \\
\text { Colombia }\end{array}$ & $2,323,787$ & 270 & 225,000 & 2 & 28 & 21 & 225,000 & 8 \\
\hline $\begin{array}{l}\text { Balboa, } \\
\text { Panama }\end{array}$ & $2,989,860$ & 442 & 300,000 & 8 & 17 & 16.5 & 5 & 7 \\
\hline $\begin{array}{l}\text { El Callo, } \\
\text { Peru }\end{array}$ & $2,054,970$ & 183 & 441,080 & 6 & 3 & 16 & 24,300 & 4 \\
\hline $\begin{array}{l}\text { Guayaquil, } \\
\text { Ecuador }\end{array}$ & $1,814,915$ & 1320 & 228,273 & 3 & 6 & 10.5 & 228,273 & 4 \\
\hline $\begin{array}{l}\text { Kingston, } \\
\text { Jamaica }\end{array}$ & $1,567,442$ & 138 & $1,037,671$ & 5 & 13 & 14 & 2400 & 11 \\
\hline $\begin{array}{l}\text { Buenos, } \\
\text { Aires, } \\
\text { Argentina }\end{array}$ & $1,352,068$ & 500 & 220,000 & 8 & 12 & 10.7 & 220,000 & 5 \\
\hline $\begin{array}{l}\text { San Anto- } \\
\text { nio, Chile }\end{array}$ & $1,287,658$ & 537 & 495,000 & 6 & 13 & 15 & 495,000 & 9 \\
\hline $\begin{array}{l}\text { San Juan, } \\
\text { Puerto Rico }\end{array}$ & $1,270,210$ & 610 & 287,273 & 0 & 6 & 17 & 287,273 & 46 \\
\hline $\begin{array}{l}\text { Bue- } \\
\text { naventura, } \\
\text { Colombia }\end{array}$ & 869,061 & 440 & 68,500 & 3 & 8 & 15 & 68,500 & 14 \\
\hline $\begin{array}{l}\text { Caucedo, } \\
\text { Dominican } \\
\text { Repulic }\end{array}$ & 918,542 & 922 & 800,000 & 2 & 6 & 15.2 & 800,000 & 15 \\
\hline $\begin{array}{l}\text { Limon } \\
\text { Moin, Costa } \\
\text { Rica }\end{array}$ & $1,115,452$ & 210 & 677,276 & 1 & 1 & 10.2 & 4930 & 6 \\
\hline $\begin{array}{l}\text { Veracus, } \\
\text { Mexico }\end{array}$ & $1,177,385$ & 507 & 402,909 & 1 & 5 & 14 & 402,909 & 11 \\
\hline $\begin{array}{l}\text { Freeport, } \\
\text { Bahamas }\end{array}$ & 965,294 & 1294 & 320,125 & 0 & 13 & 16 & 57,000 & 3 \\
\hline Itajai, Brazil & $1,200,000$ & 1035 & 180,000 & 3 & 2 & 14 & 180,000 & 4 \\
\hline $\begin{array}{l}\text { Valparado, } \\
\text { Chile }\end{array}$ & $1,104,143$ & 740 & 280,710 & 5 & 3 & 14 & 280,710 & 3 \\
\hline $\begin{array}{l}\text { Altamica, } \\
\text { Mexico }\end{array}$ & 884,030 & 973 & 396,570 & 1 & 4 & 12 & 600 & 12 \\
\hline
\end{tabular}




\section{Acknowledgements}

The article processing charge of this work is supported by China Merchants Energy Shipping. Special thanks to Tokyo University of Marine Science and Technology (TUMSAT) and Japan Internation Cooperation Agency (JICA) for their invaluable support.

\section{Authors' contributions}

Professor Tetsuro Hyodo is advisor for this research and was instrumental in recommending the appropriate methodology for this article. Both authors read and approved the final manuscript.

\section{Authors' information}

Professor Tetsuro Hyodo, Head of the Department of Logistics and Information Engineering. He graduated in Civil Engineering, Tokyo Institute of Technology in 1984. In 1986, completed the master's Course in Civil Engineering at the Graduate School. 1989.Completed the Doctoral Course (Doctor of Engineering). 1998, Visiting Researcher at the Institute of Transportation Research, University of California, Berkeley. He is the author and co-author of several research journals, please see link https://tumsatdb.kaiyodai.ac.jp/html/100000623_ronbn_1_en.html.

Kahuina Hassan Miller, 2nd year Doctoral Student from the Tokyo University of Marine Science and Technology (TUMSAT). Course of Applied Marine Environmental Studies specialization logistics and information engineering. He is the graduate World Maritime University (2014), obtaining MSc in Maritime Affair specialization Ship management and Logistics.

\section{Funding}

All funding for this research is sponsored by the Japan International Corporation Agency (JICA). JICA provides an annual academic budget for research. This budget is managed by Professor Tetsuro Hyodo, Tokyo University of Marine Science and Technology (TUMSAT) from the Department of Logistics and Information engineering.

\section{Availability of data and materials}

CEPAL (2019). Port Activity report of Latin America and Caribbean. https://www.cepal.org/en/notes/port-activity-reportlatin-america-and-caribbean-2018; United Nations Conference on Trade and Development. (UNCTAD). https://unctad. org/en/Pages/statistics.aspx; Clarkson Research data 2020. https://www.clarksons.net/portal; Container Port traffic (TEU: 20 Foot equivalent units). https://data.worldbank.org/indicator/IS.SHP.GOOD.TU; Latin America and Caribbean Ports. http://perfil.cepal.org///en/portmovements_classic.html.

\section{Declarations}

\section{Competing interests}

Authors declares no competing interests.

Received: 13 October 2021 Accepted: 10 December 2021

Published online: 07 January 2022

\section{References}

Aigner D, Lovell C, Schmidt P (1977) Formulation and estimation of stochastic frontier production function models. J Econom 6(1):21-37. https://doi.org/10.1016/0304-4076(77)90052-5

Aminatou M, Jiaqi Y, Okyere S (2018) Evaluating the impact of long cargo dwell time on port performance: an evaluation model of Douala International Terminal in Cameroon. Arch Transp 46(2):7-20. https://doi.org/10.5604/01.3001.0012. 2098

Bhadury J (2016) Panama Canal expansion and its impact on East and Gulf Coast ports of USA. Marit Policy Manag 43(8):928-944. https://doi.org/10.1080/03088839.2016.1213439

Blonigen BA, Wilson WW (2007) Port efficiency and trade flows*. Rev Int Econ 16(1):21-36. https://doi.org/10.1111/j.14679396.2007.00723.x

Caribbean Development Bank (CDB) (2017) Transforming the caribbean port services industry: towards the efficiency frontier [E-book]. Caribbean Development Bank, Bridgetown

Çelebi D (2017) The role of logistics performance in promoting trade. Marit Econ Logist 21(3):307-323. https://doi.org/10. 1057/s41278-017-0094-4

CEPAL (2019) Port activity report of Latin America and the Caribbean 2018 | Briefing note | Economic Commission for Latin America and the Caribbean. Economic Commission for Latin America and the Caribbean. https://www.cepal. org/en/notes/port-activity-report-latin-america-and-caribbean-2018

CEPAL (2020) Economic Commission for Latin America and the Caribbean. Ports. http://perfil.cepal.org/l/en/portm ovements_classic.html

Çetin SB, Balcı G, Esmer S (2017) Effects of prolonged port privatization process: a case study of port of IZMiR alsancak. Dokuz Eylül Üniversitesi Denizcilik Fakültesi Dergisi 1309-4246:114-134. https://doi.org/10.18613/deudfd. 351630

Clark X, Dollar D, Micco A (2004) Port efficiency, maritime transport costs, and bilateral trade. NBER Working Papers, 417-450. https://doi.org/10.3386/w10353

Cullinane K, Wang TF, Song DW, Ji P (2006) The technical efficiency of container ports: comparing data envelopment analysis and stochastic frontier analysis. Transp Res Part A Policy Pract 40(4):354-374. https://doi.org/10.1016/j. tra.2005.07.003

Da Silva F, Rocha C (2012) A demand impact study of southern and southeastern ports in Brazil: an indication of port competition. Marit Econ Logist 14:204-219. https://doi.org/10.1057/mel.2012.4 
De Langen PW, Sharypova K (2013) Intermodal connectivity as a port performance indicator. Res Transp Bus Manag 8:97-102. https://doi.org/10.1016/j.rtbm.2013.06.003

Encyclopedia (2021) Stochastic frontier analysis | Encyclopedia.com. Encyclopedia.Com. https://www.encyclopedia.com/ social-sciences/applied-and-social-sciences-magazines/stochastic-frontier-analysis

Figueiredo De Oliveira G, Cariou P (2015) The impact of competition on container port (in)efficiency. Transp Res Part A Policy Pract 78:124-133. https://doi.org/10.1016/j.tra.2015.04.034

Gani A (2017) The logistics performance effect in international trade. Asian J Shipp Logist 33(4):279-288. https://doi.org/ 10.1016/j.ajs. 2017.12 .012

Hassan R, Gurning R, Handani D (2017) Analysis of the container dwell time at container terminal by using simulation modelling. Int J Mar Eng Innov Res 1(3):2320. https://doi.org/10.12962/j25481479.v1i3.2320

Herrera S, Pang G (2008) Efficiency of infrastructure: the case of container ports. Economia 9:165-194. https://core.ac.uk/ download/pdf/6535717.pdf

IMF (2001) Global trade liberalization and the developing countries—an IMF issues brief. International Monetary Fund. https://www.imf.org/external/np/exr/ib/2001/110801.htm

Jung BM (2011) Economic contribution of ports to the local economies in Korea. Asian J Shipp Logist 27(1):1-30. https:// doi.org/10.1016/s2092-5212(11)80001-5

Kuosmanen T, Kortelainen M (2010) Stochastic non-smooth envelopment of data: semi-parametric frontier estimation subject to shape constraints. J Prod Anal 38(1):11-28. https://doi.org/10.1007/s11123-010-0201-3

Langen P, Nijdam M, Van der Horst M (2007) New indicators to measure port performance. J Marit Res JMR 4(1):23-36. 4. ISSN 1697-4840. https://www.researchgate.net/publication/28199982_New_indicators_to_measure_port_perfo rmance

Lonza L, Marolda MC (2016) Ports as drivers of urban and regional growth. Trans Res Proced 14:2507-2516. https://doi. org/10.1016/j.trpro.2016.05.327

Melalla O, Vyshka E, Lumi D (2016) Defining the most important port performance indicators: a case of albanian ports. Int J Econ , Commer Manag U K 3(10):808-819. http://ijecm.co.uk/wp-content/uploads/2015/10/31049.pdf

Merk O, Dang T (2012) The efficiency of World Ports in container and Bulk Cargo (oil, coal, ores and grain). OECD Regional Development Working Papers, 9-22. https://doi.org/10.1787/5k92vgw39zs2-en

Mudronja G, Jugović A, Škalamera-Alilović D (2020) Seaports and economic growth: panel data analysis of EU Port Regions. J Mar Sci Eng 8(12):1017. https://doi.org/10.3390/jmse8121017

Munim ZH, Schramm HJ (2018) The impacts of port infrastructure and logistics performance on economic growth:the mediating role of seaborne trade. J Ship Trade 3(1). https://doi.org/10.1186/s41072-018-0027-0

Naanwaab C, Diarrassouba M (2013) The impact of economic freedom on bilateral trade: a cross-country analysis. Int J Business Manag Econ Res 4(1):668-672

Nogué-Algueró B (2019) Growth in the docks: ports, metabolic flows and socio-environmental impacts. Sustain Sci 15(1):11-30. https://doi.org/10.1007/s11625-019-00764-y

Notteboom T, Coeck C, Van Den Broeck J (2000) Measuring and explaining the relative efficiency of container terminals by means of Bayesian stochastic frontier models. Int J Marit Econ 2(2):83-106. https://doi.org/10.1057/ijme.2000.9

Notteboom T, Pallis A, Rodrigue JP (2021, March 28) Port economics, management, and policy. Port economics, management, and policy |A comprehensive analysis of the port industry. https://porteconomicsmanagement.org

Pallis A, Rodrigue JP (2021) Chapter 6.2-Port efficiency | Port economics, management and policy. Port economics, management and policy |A comprehensive analysis of the port industry. https://porteconomicsmanagement.org/ pemp/contents/part6/port-efficiency/

Park C, Richardson HW, Park J (2020) Widening the Panama Canal and US ports: historical and economic impact analyses. Marit Policy Manag 47(3):419-433. https://doi.org/10.1080/03088839.2020.1721583

Pérez I, Trujillo L, González MM (2016) Efficiency determinants of container terminals in Latin American and the Caribbean. Util Policy 41:1-14. https://doi.org/10.1016/j.jup.2015.12.001

PortStrategy (2020) Container dwell time prediction solution. https://www.portstrategy.com/news101/port-operations/ cargo-handling/1252746.article

Rodrigue J (2020) Geography of transport systems, 5th edn. The Geography of Transport Systems. https://transportg eography.org/geography-of-transport-systems-5th-edition/

Rodrigue JP, Notteboom T (2021, January 7) Chapter 7.2-Ports and economic development | Port economics, management and policy. Port economics, management and policy | A comprehensive analysis of the port industry. https:// porteconomicsmanagement.org/pemp/contents/part7/port-and-economic-development/\#:\%7E:text=Ports\% 20are\%20catalysts\%20for\%20economic,direct\%2C\%20indirect\%2C\%20and\%20induced

Sarriera J, Suárez-Alemán A, Serebrisky T, Trujillo L (2015) When it comes to container port efficiency, are all developing regions equal? (IDB Working Paper Series no. IDB-WP-568). https://publications.iadb.org/publications/english/ document/When-It-Comes-to-Container-Port-Efficiency-Are-All-Developing-Regions-Equal.pdf

Serebrisky T, Sarriera JM, Suárez-Alemán A, Araya G, Briceño-Garmendía C, Schwartz J (2016) Exploring the drivers of port efficiency in Latin America and the Caribbean. Trans Policy 45:31-45. https://doi.org/10.1016/j.tranpol.2015.09.004

Shetty DK, Dwarakish G (2018) Measuring port performance and productivity. ISH J Hydraul Eng 26(2):221-227. https:// doi.org/10.1080/09715010.2018.1473812

Suárez-Alemán A, Morales Sarriera J, Serebrisky T, Trujillo L (2016) When it comes to container port efficiency, are all developing regions equal? Transp Res Part A Policy Pract 86:56-77. https://doi.org/10.1016/j.tra.2016.01.018

Suárez-Alemán A, Serebrisky T, Ponce de León O (2017) Port reforms in Latin America and the Caribbean: where we stand, how we got here, and what is left. Marit Econ Logist 20(4):495-513. https://doi.org/10.1057/ s41278-017-0086-4

Talley WK (2006) Chapter 22—Port performance: an economics perspective. Res Transp Econ 17:499-516. https://doi.org/ 10.1016/S0739-8859(06)17022-5

Talley WK (2017) Port economics (Routledge maritime masters), 2nd edn. [E-book]. Routledge. https://www.routledge. com/Port-Economics/Talley/p/book/9781138952195 
Tongzon JL (1995) Determinants of port performance and efficiency. Transp Res Part A Policy Pract 29(3):245-252. https://doi.org/10.1016/0965-8564(94)00032-6

Tongzon J, Heng W (2005) Port privatization, efficiency, and competitiveness: some empirical evidence from container ports (terminals). Transp Res Part A Policy Pract 39(5):405-424. https://doi.org/10.1016/j.tra.2005.02.001

Töngür N, Türkcan K, Ekmen-Özçelik S (2020) Logistics performance and export variety: evidence from Turkey. Central Bank Rev 20(3):143-154. https://doi.org/10.1016/j.cbrev.2020.04.002

Tran DV (2019) A study on the impact of economic freedom on economic growth in ASEAN countries. Business Econ Horizons (BEH) 15(3):423-449. https://doi.org/10.22004/ag.econ.301155

UNCTAD (2016) UNCTAD port management series—volume 4. www.unctad.org/Trainfortrade. https://unctad.org/ system/files/official-document/dtlkdb2016d1_en.pdf

UNCTAD (2019) Review of maritime transport 2019, Chapter 3. UNCTAD 2019. https://unctad.org/system/files/officialdocument/rmt2019ch3_en.pdf

UNCTAD (2020) Maritime transport. https://unctadstat.unctad.org/wds/ReportFolders/reportFolders.aspx

UNCTAD (2021a) Port liner shipping connectivity index, quarterly. UNCTAD STAT. https://unctadstat.unctad.org/wds/? aspxerrorpath $=/ \mathrm{wds} /$ TableViewer/tableView.aspx

UNCTAD (2021b) Review of maritime transport 2021. https://unctad.org/webflyer/review-maritime-transport-2021

Wilmsmeier G, Monios J (2016) Container ports in Latin America: Challenges in a changing global economy. Dynam Ship Port Develop Glob Econ 11-52. https://doi.org/10.1057/9781137514233_2

World Bank (2019) Container port traffic (TEU: $20 \mathrm{ft}$ equivalent units) | data. World Bank. https://data.worldbank.org/indic ator/IS.SHP.GOOD.TU

World Bank (2020) Container port traffic (TEU: $20 \mathrm{ft}$ equivalent units) | data. World Bank. https://data.worldbank.org/indic ator/IS.SHP.GOOD.TU

World Bank (2021) Liner shipping connectivity index (maximum value in 2004 = 100)—Latin America \& Caribbean | Data. Liner Shipping Connectivity Index. https://data.worldbank.org/indicator/IS.SHP.GCNW.XQ?locations=ZJ

World Economic Forum (2018) The global competitiveness index 4.0 methodology and technical notes. The Global Competitiveness Report. http://www3.weforum.org/docs/GCR2018/04Backmatter/3.\%20Appendix\%20C.pdf

World Port Source (2021) WPS—Home Page. http://www.worldportsource.com/

Yang H, Lin K, Kennedy OR, Ruth B (2011) Seaport operational efficiency: an evaluation of five Asian ports using stochastic frontier production function model. J Serv Sci Manag 04(03):391-399. https://doi.org/10.4236/jssm.2011.43045

\section{Publisher's Note}

Springer Nature remains neutral with regard to jurisdictional claims in published maps and institutional affiliations. 